University of Nebraska - Lincoln

DigitalCommons@University of Nebraska - Lincoln

Public Health Resources

Public Health Resources

2011

\title{
HIV-1 adaptation to NK-cell-mediated immune pressure
}

Galit Alter

Ragon Institute at MGH

David Heckerman

Microsoft Research

Arne Schneidewind

Ragon Institute at MGH

Lena Fadda

Ragon Institute at MGH

Carl M. Kadie

Microsoft Research

See next page for additional authors

Follow this and additional works at: https://digitalcommons.unl.edu/publichealthresources

Part of the Public Health Commons

Alter, Galit; Heckerman, David; Schneidewind, Arne; Fadda, Lena; Kadie, Carl M.; Carlson, Jonathan M.; Oniangue-Ndza, Cesar; Martin, Maureen; Li, Bin; Khakoo, Salim I.; Carrington, Mary; Allen, Todd M.; and Altfeld, Marcus, "HIV-1 adaptation to NK-cell-mediated immune pressure" (2011). Public Health Resources. 134.

https://digitalcommons.unl.edu/publichealthresources/134

This Article is brought to you for free and open access by the Public Health Resources at DigitalCommons@University of Nebraska - Lincoln. It has been accepted for inclusion in Public Health Resources by an authorized administrator of DigitalCommons@University of Nebraska - Lincoln. 


\section{Authors}

Galit Alter, David Heckerman, Arne Schneidewind, Lena Fadda, Carl M. Kadie, Jonathan M. Carlson, Cesar Oniangue-Ndza, Maureen Martin, Bin Li, Salim I. Khakoo, Mary Carrington, Todd M. Allen, and Marcus Altfeld 


\title{
HIV-1 adaptation to NK-cell-mediated immune pressure
}

\author{
Galit Alter ${ }^{1 *}$, David Heckerman ${ }^{2 *}$, Arne Schneidewind ${ }^{1 *}$, Lena Fadda $^{1 *}$, Carl M. Kadie $^{2}$, Jonathan M. Carlson ${ }^{2}$, \\ Cesar Oniangue-Ndza ${ }^{1}$, Maureen Martin ${ }^{3}$, Bin Li ${ }^{1}$, Salim I. Khakoo ${ }^{4}$, Mary Carrington ${ }^{1,3}$, Todd M. Allen ${ }^{1}$ \& Marcus Altfeld ${ }^{1}$
}

Natural killer (NK) cells have an important role in the control of viral infections, recognizing virally infected cells through a variety of activating and inhibitory receptors ${ }^{1-3}$. Epidemiological and functional studies have recently suggested that NK cells can also contribute to the control of HIV-1 infection through recognition of virally infected cells by both activating and inhibitory killer immunoglobulin-like receptors $(\mathrm{KIRs})^{4-7}$. However, it remains unknown whether NK cells can directly mediate antiviral immune pressure in vivo in humans. Here we describe KIR-associated amino-acid polymorphisms in the HIV-1 sequence of chronically infected individuals, on a population level. We show that these KIR-associated HIV-1 sequence polymorphisms can enhance the binding of inhibitory KIRs to HIV-1-infected $\mathrm{CD}^{+}{ }^{+} \mathrm{T}$ cells, and reduce the antiviral activity of KIR-positive NK cells. These data demonstrate that KIR-positive NK cells can place immunological pressure on HIV-1, and that the virus can evade such NK-cellmediated immune pressure by selecting for sequence polymorphisms, as was previously described for virus-specific $T$ cells and neutralizing antibodies ${ }^{8}$. NK cells might therefore have a previously underappreciated role in contributing to viral evolution.

We hypothesized that HIV-1 can evade recognition by NK cells through the selection of sequence polymorphisms in regions targeted by KIRs, and that KIR-associated polymorphisms in the HIV-1 sequence can be identified on a population level. To test this hypothesis, we examined the relationship between KIR genotypes and HIV-1 polymorphisms in a cohort of 91 untreated, chronically HIV-1-infected individuals (Supplementary Table 1), in whom full-length HIV-1 sequences were determined and HLA-class-I-associated polymorphisms were previously described ${ }^{9}$. We used a decision-tree approach that corrects for phylogenetic structure among the sequences and allows for a multivariate analysis to identify KIR-associated sequence polymorphisms ${ }^{10}$. This analysis led to the identification of 22 positions in the HIV-1 genome at which amino-acid polymorphisms were significantly associated with the presence of a specific KIR gene (Table 1 and Supplementary Fig. 1). Taken together, these data show that HIV-1 can adapt to host KIR genotypes on a population level.

To assess the consequences of these KIR-associated amino-acid polymorphisms for NK-cell-mediated recognition of cells infected with HIV-1, we initially evaluated polymorphisms in a region of HIV-1 that encodes an overlapping segment that spans the carboxy-terminal end of $\mathrm{Vpu}$ and the amino-terminal end of Env (polymorphisms 15-18 in Table 1 and Supplementary Fig. 1). We selected this region because these polymorphisms were present in both reading frames at significantly higher frequencies in individuals that possessed at least one copy of the KIR2DL2 gene than in individuals that did not (Table 2 and Supplementary Tables 2 and 3). In amino-acid positions 71 and 74 of $\mathrm{Vpu}, \mathrm{HIV}-1$ sequences derived from KIR2DL2-positive individuals encoded a methionine in position $\mathrm{Vpu}(71)$ and a histidine in position
$\mathrm{Vpu}(74)$ in more than $70 \%$ of cases. Because of the overlapping Vpu/ Env coding region, these positions of Vpu corresponded to a tryptophan in position $\operatorname{Env}(17)$ and a methionine in position $\operatorname{Env}(20)$, respectively. The $\mathrm{Vpu}(71 \mathrm{M} / 74 \mathrm{H})(\mathrm{Env}(17 \mathrm{~W} / 20 \mathrm{M}))$ sequence was significantly less frequent in HIV-1-infected individuals that did not encode KIR2DL2 $(P<0.0001)$. Furthermore, the presence of the $\mathrm{Vpu}(71 \mathrm{M})$ polymorphism was in strong linkage disequilibrium with the $\mathrm{Vpu}(74 \mathrm{H})$ polymorphism $\left(P=3.17^{-12}\right)$. Taken together, these data demonstrate a significant enrichment of HIV-1 viruses containing the $\mathrm{Vpu}(71 \mathrm{M} / 74 \mathrm{H})(\operatorname{Env}(17 \mathrm{~W} / 20 \mathrm{M}))$ polymorphism in individuals encoding KIR2DL2.

To determine the functional consequences of these KIR2DL2-associated polymorphisms in $\mathrm{Vpu}$ and Env, we constructed HIV-1 viral variants using the backbone of the HIV-1 NL4-3 strain ${ }^{11,12}$. These variants encoded either the $\mathrm{Vpu}(71 \mathrm{M} / 74 \mathrm{H})(\operatorname{Env}(17 \mathrm{~W} / 20 \mathrm{M}))$ sequence that was seen in KIR2DL2 ${ }^{+}$individuals (referred to as $\mathrm{Vpu}-\mathrm{Env}^{\mathrm{V} / \mathrm{V}}$, with 'V' standing for variant), or the $\operatorname{Vpu}(71 \mathrm{R} / 74 \mathrm{~L})(\operatorname{Env}(17 \mathrm{G} / 20 \mathrm{~L})$ ) sequence that was most commonly seen in KIR2DL2 ${ }^{-}$subjects (referred to as $\mathrm{Vpu}-\mathrm{Env}^{\mathrm{WT} / \mathrm{WT}}$ ). No significant differences were observed in the ability of the viral variants to replicate in primary $\mathrm{CD}^{+} \mathrm{T}$ cells in vitro (Supplementary Fig. 2a). We subsequently assessed whether the different viral variants had any impact on NKcell recognition and/or antiviral activity. Primary $\mathrm{CD}^{+}{ }^{+} \mathrm{T}$ cells were infected with viruses containing either the $\mathrm{Vpu}-\mathrm{Env}^{\mathrm{V} / \mathrm{V}}$ or the $\mathrm{Vpu}-$ $\mathrm{Env}^{\mathrm{WT} / \mathrm{WT}}$ sequence, and then placed in co-culture with autologous NK

\begin{tabular}{|c|c|c|c|c|c|}
\hline & Protein & $\begin{array}{l}\text { Amino-acid } \\
\text { position }\end{array}$ & KIR association & $\begin{array}{l}\text { Consensus } \\
\text { amino acid* }\end{array}$ & $Q$ value \\
\hline 1 & Gag & 93 & KIR2DS3 & $E$ & 0.1389 \\
\hline 2 & Gag & 138 & KIR2DL2 & $\bar{L}$ & 0.1852 \\
\hline 3 & Gag & 138 & KIR2DS2 & $\mathrm{L}$ & 0.1852 \\
\hline 4 & Gag & 371 & KIR2DS5 & $\mathrm{T}$ & 0 \\
\hline 5 & Gag & 389 & KIR3DS1 & $\mathrm{T}$ & 0 \\
\hline 6 & Gag & 479 & KIR2DS1 & I & 0 \\
\hline 7 & Vpr & 37 & KIR2DS3 & I & 0.0909 \\
\hline 8 & Tat & 3 & KIR2DL2 & $\mathrm{S}$ & 0.0246 \\
\hline 9 & Tat & 3 & KIR2DS2 & $\mathrm{S}$ & 0 \\
\hline 10 & Tat & 3 & KIR3DS1 & $\mathrm{S}$ & 0.1311 \\
\hline 11 & Tat & 9 & KIR2DS3 & $\mathrm{P}$ & 0.1311 \\
\hline 12 & Tat & 28 & KIR2DS1 & V & 0.1311 \\
\hline 13 & Tat & 28 & KIR2DS5 & V & 0.1339 \\
\hline 14 & Vpu & 3 & KIR2DL3 & S & 0.0833 \\
\hline 15 & Vpu & 71 & KIR2DL2 & M & 0.125 \\
\hline 16 & Vpu & 74 & KIR2DL2 & $\mathrm{H}$ & 0.1354 \\
\hline 17 & Env & 17 & KIR2DL2 & W & 0 \\
\hline 18 & Env & 20 & KIR2DL2 & $\mathrm{M}$ & 0.1667 \\
\hline 19 & Env & 46 & KIR3DS1 & K & 0.1667 \\
\hline 20 & Env & 347 & KIR2DS1 & $\mathrm{L}$ & 0.2 \\
\hline 21 & Env & 595 & KIR2DS1 & I & 0.2 \\
\hline 22 & Nef & 9 & KIR2DL2 & $\mathrm{S}$ & 0.0833 \\
\hline
\end{tabular}

*HIV-1 consensus sequence in the 91 study subjects. UK. 
Table 2 | Frequency of amino-acid polymorphisms among KIR2DL2 ${ }^{+}$and KIR2DL2- ${ }^{-}$subjects

\begin{tabular}{|c|c|c|c|c|c|c|c|c|c|c|c|c|}
\hline \multirow[t]{2}{*}{ KIR2DL2 status } & \multicolumn{10}{|c|}{ Vpu (amino-acid position) } & \multirow[t]{2}{*}{ Percentage of individuals } & \multirow[t]{2}{*}{ Number of individuals } \\
\hline & $E(70)$ & M (71) & $G(72)$ & $\mathrm{H}(73)$ & $H(74)$ & $A(75)$ & $P(76)$ & W (77) & $\mathrm{D}(78)$ & $V(79)$ & & \\
\hline \multirow[t]{3}{*}{${\mathrm{KIR} 2 \mathrm{DL} 2^{+}}^{+}$} & $\cdot / P / D$ & . & . & . & . & . & . & . & $\mathrm{N} / \cdot$ & $\mathrm{l} / \cdot$ & 72 & $(34 / 47)$ \\
\hline & $\cdot$ & $\mathrm{L} / \mathrm{Q} /-/$ & . & . & $\mathrm{D} / \mathrm{L} / \cdot$ & . & . & . & $\cdot$ & $\mathrm{l} /$ & 24 & $(11 / 47)$ \\
\hline & . & $\mathrm{R}$ & . & . & L & . & . & . & . & $1 /$ & 4 & $(2 / 47)$ \\
\hline \multirow[t]{3}{*}{$\mathrm{KIR} \mathrm{DL} 2^{-}$} & $\cdot / \mathrm{D}$ & . & $\cdot / E$ & $\cdot / \mathrm{Q}$ & . & $\cdot / \mathrm{D}$ & . & . & . & . & 32 & $(14 / 44)$ \\
\hline & $\cdot / \mathrm{H} / \mathrm{M}$ & N/V/Q/G & $\cdot / A$ & . & $D / R$ & . & $\cdot / L$ & $\cdot / G$ & $\cdot / \mathrm{V}$ & $\cdot / 1$ & 34 & $(15 / 44)$ \\
\hline & $\cdot / \mathrm{H}$ & $\mathbf{R}$ & . & $\cdot / R$ & $\mathrm{~L}$ & . & $\cdot / L$ & $\cdot / G / R / L$ & $\cdot / \mathrm{V}$ & $\cdot / /$ & 34 & $(15 / 44)$ \\
\hline \multirow[t]{2}{*}{ KIR2DL2 status } & \multicolumn{10}{|c|}{ Env (amino-acid position) } & \multirow[t]{2}{*}{ Percentage of individuals } & \multirow[t]{2}{*}{ Number of individuals } \\
\hline & $R(16)$ & $\begin{array}{l}W \\
(17)\end{array}$ & $\begin{array}{c}G \\
(18)\end{array}$ & $\begin{array}{c} \\
(19)\end{array}$ & $\begin{array}{c}M \\
(20)\end{array}$ & $\begin{array}{c} \\
(21)\end{array}$ & $\begin{array}{c}L \\
(22)\end{array}$ & $\begin{array}{c}G \\
(23)\end{array}$ & $\begin{array}{c}M \\
(24)\end{array}$ & $\mathrm{L}(25)$ & & \\
\hline \multirow[t]{3}{*}{$\overline{\mathrm{KIR}^{2} \mathrm{DL} 2^{+}}$} & $\cdot / \mathrm{K}$ & . & . & $\cdot / /$ & . & . & . & . & $\cdot / / \mathrm{L} / \mathrm{I}$ & . & 85 & $(40 / 47)$ \\
\hline & $\cdot / \mathrm{K}$ & $\mathrm{R} / \cdot$ & . & 1 & $\mathrm{~T} / \cdot$ & . & . & . & . & . & 11 & $(5 / 47)$ \\
\hline & $\cdot / \mathrm{K}$ & G & . & $1 / A$ & $\mathrm{~L}$ & $\cdot / F$ & . & . & $\cdot / 1$ & . & 4 & $(2 / 47)$ \\
\hline \multirow{3}{*}{$\mathrm{KIR} \mathrm{DL} 2^{-}$} & $\cdot / \mathrm{K}$ & . & . & $\cdot / /$ & . & . & . & . & $\cdot / /$ & . & 43 & $(19 / 44)$ \\
\hline & $\cdot$ & $\mathrm{R} / \mathrm{M}$ & . & $\cdot / /$ & $\cdot / \mathrm{V}$ & . & . & . & $\cdot / /$ & . & 23 & $(10 / 44)$ \\
\hline & $\cdot / \mathrm{K}$ & G & $\cdot$ & $\cdot / 1$ & $\mathbf{L}$ & $\cdot$ & · & · & $\cdot / /$ & · & 34 & $(15 / 44)$ \\
\hline \multirow[t]{2}{*}{ KIR2DL2 status } & \multicolumn{10}{|c|}{ Gag (amino-acid position) } & \multirow[t]{2}{*}{ Percentage of individuals } & \multirow[t]{2}{*}{ Number of individuals } \\
\hline & I (134) & $\begin{array}{c}V \\
(135)\end{array}$ & $\begin{array}{c}Q \\
(136)\end{array}$ & $\begin{array}{c}\mathrm{N} \\
(137)\end{array}$ & $\begin{array}{c}\mathrm{L} \\
\text { (138) }\end{array}$ & $\begin{array}{c}\mathrm{Q} \\
(139)\end{array}$ & $\begin{array}{c}G \\
(140)\end{array}$ & $\begin{array}{c}Q Q \\
(141)\end{array}$ & $\begin{array}{c}\mathrm{M} \\
(142)\end{array}$ & $V(143)$ & & \\
\hline \multirow[t]{3}{*}{$\overline{\mathrm{KIR}^{2} \mathrm{DL} 2^{+}}$} & . & . & $\cdot$ & . & . & . & . & . & . & $\cdot / /$ & 68 & $(32 / 47)$ \\
\hline & $\cdot / \mathrm{V}$ & . & . & . & $M / V / A$ & . & . & . & . & $\cdot / 1$ & 32 & $(15 / 47)$ \\
\hline & . & . & . & . & I & . & . & . & . & . & 0 & $(0 / 47)$ \\
\hline \multirow[t]{3}{*}{$\mathrm{KIR} 2 \mathrm{DL} 2^{-}$} & . & . & $\cdot / \mathrm{R}$ & . & . & . & . & . & . & . & 57 & $(25 / 44)$ \\
\hline & . & . & $\cdot / \mathrm{R}$ & . & $M / V / A$ & . & . & . & . & . & 25 & $(11 / 44)$ \\
\hline & . & . & . & . & I & . & . & · & . & . & 18 & $(8 / 44)$ \\
\hline \multirow[t]{2}{*}{ KIR2DL2 status } & \multicolumn{10}{|c|}{ Nef (amino-acid position) } & \multirow[t]{2}{*}{ Percentage of individuals } & \multirow[t]{2}{*}{ Number of individuals } \\
\hline & W (5) & $\begin{array}{c}S \\
(6)\end{array}$ & $\begin{array}{c}\text { K } \\
(7)\end{array}$ & $\begin{array}{c}R \\
(8)\end{array}$ & $\begin{array}{c}\text { S } \\
(9)\end{array}$ & $\begin{array}{c}V \\
(10)\end{array}$ & $\begin{array}{c}\mathrm{V} \\
(11)\end{array}$ & $\begin{array}{c}G \\
(12)\end{array}$ & $\begin{array}{c}W \\
\text { (13) }\end{array}$ & $P(14)$ & & \\
\hline \multirow[t]{3}{*}{$\overline{\mathrm{KIR}^{2} \mathrm{DL} 2^{+}}$} & $\cdot / X$ & . & . & $\cdot / \mathrm{X}$ & . & $\cdot / X$ & $\cdot / X$ & $\cdot / X$ & . & $\cdot / \mathrm{X}$ & 75 & $(35 / 47)$ \\
\hline & $\cdot / X$ & . & . & $\cdot / X$ & $E / R / N / C / L /-$ & $\cdot / X$ & $\cdot / X$ & $\cdot / \mathrm{E}$ & . & $\cdot / X$ & 23 & (11/47) \\
\hline & . & . & . & $\cdot$ & $\mathrm{K}$ & $\mathrm{E}$ & $\mathrm{N}$ & . & . & $\mathrm{S}$ & 2 & $(1 / 47)$ \\
\hline \multirow[t]{3}{*}{ KIR2DL2- } & $\cdot / \mathrm{C}$ & . & $\cdot / \mathrm{R}$ & $\cdot / X$ & . & $\cdot / X$ & $\cdot / X$ & $\cdot / X$ & . & $\cdot / X$ & 52 & $(23 / 44)$ \\
\hline & $\cdot / \mathrm{C}$ & . & $\cdot / \mathrm{R}$ & $\cdot / X$ & $-/ P / R / I / G / W$ & $\cdot / X$ & $\cdot / X$ & $\cdot / X$ & . & $\cdot / X$ & 27 & (12/44) \\
\hline & . & . & . & $\cdot / X$ & $\mathrm{~K}$ & $\cdot / X$ & $\cdot / X$ & $\cdot / D$ & . & $\cdot / S$ & 21 & $(9 / 44)$ \\
\hline
\end{tabular}

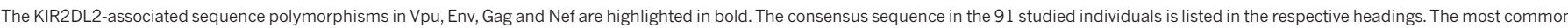

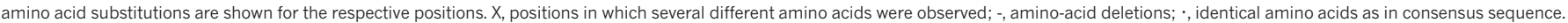
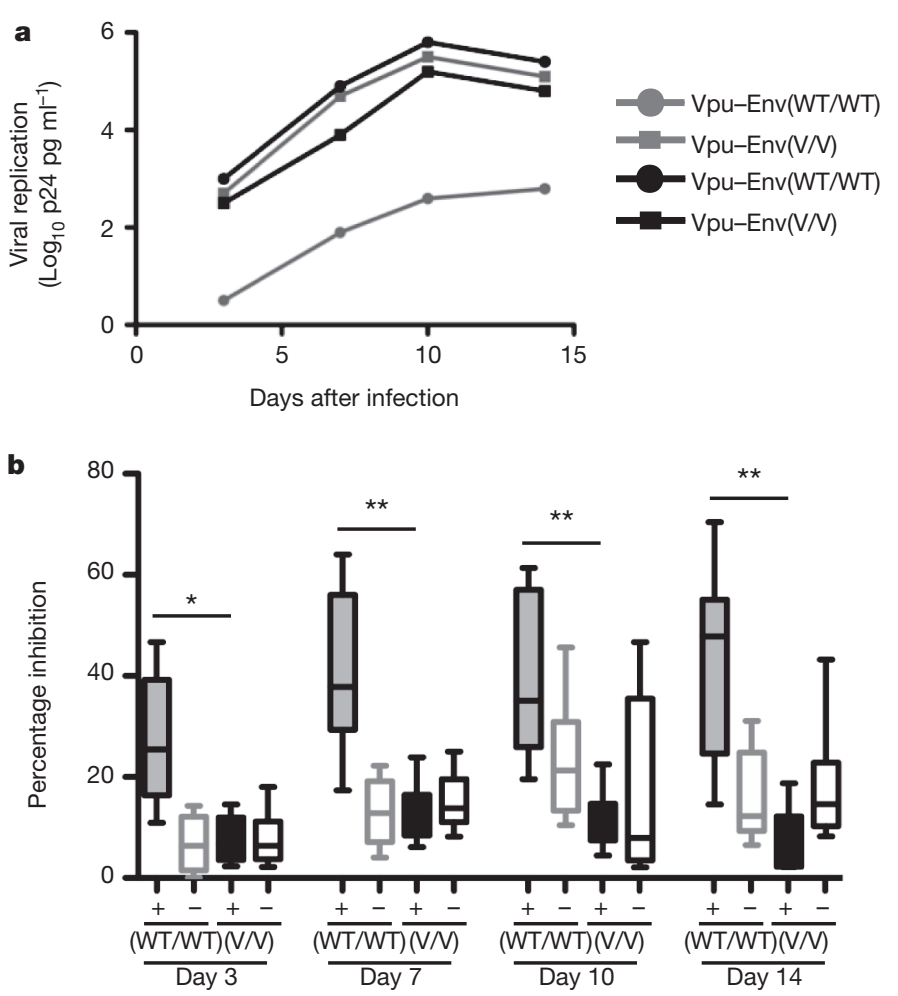

cells derived from KIR2DL2 ${ }^{+}$or KIR2DL2 ${ }^{-}$HIV-1-negative individuals (Fig. 1). Both viruses replicated well in the presence of KIR2DL2 NK cells, with less than half a log inhibition of viral replication in the presence of NK cells compared to replication in $\mathrm{CD} 4^{+} \mathrm{T}$ cells alone (Fig. 1a, b). In contrast, the Vpu-Env ${ }^{\mathrm{WT} / \mathrm{WT}}$ virus was markedly inhibited by NK cells derived from KIR2DL2 ${ }^{+}$, but not KIR2DL2 ${ }^{-}$, subjects (Fig. 1b). Thus, the $\mathrm{Vpu}-\mathrm{Env}^{\mathrm{V} / \mathrm{V}}$ virus, which contains polymorphisms that were strongly associated with the presence of KIR2DL2 on the population level, was not inhibited by KIR2DL2 ${ }^{+} \mathrm{NK}$ cells in vitro, whereas the 'wild-type' variant that was rarely observed in KIR2DL2 individuals was strongly inhibited by KIR2DL2 ${ }^{+} \mathrm{NK}$ cells, consistent with the selection of $\mathrm{Vpu}-\mathrm{Env}^{\mathrm{V} / \mathrm{V}}$ viruses in KIR2DL2 ${ }^{+}$individuals.

To elucidate further the mechanism by which KIR2DL2 ${ }^{+} \mathrm{NK}$ cells inhibit replication of $\mathrm{Vpu}-\mathrm{Env}^{\mathrm{WT}}{ }^{\mathrm{WT}}$ viruses, we monitored the induction of CD107a expression on NK cells in vitro after stimulation with autologous $\mathrm{CD} 4^{+} \mathrm{T}$ cells infected with either the V pu-Env ${ }^{\mathrm{WT} / \mathrm{WT}}$

Figure $1 \mid$ KIR2DL2-associated sequence polymorphisms result in a loss of inhibition of HIV replication by NK cells in vitro. a, The Vpu-Env ${ }^{\mathrm{WT} / \mathrm{WT}}$ virus was inhibited more robustly than the $\mathrm{Vpu}-\mathrm{Env}^{\mathrm{V} / \mathrm{V}}$ virus by NK cells derived from a KIR2DL2 ${ }^{+}$individual (grey lines). NK cells derived from a KIR2DL2 ${ }^{-}$individual (black lines) did not inhibit either virus. b, The Vpu$\mathrm{Env}^{\mathrm{WT} / \mathrm{WT}}$ virus (dark grey bars) was inhibited significantly more strongly than the $\mathrm{Vpu}-\mathrm{Env}^{\mathrm{V} / \mathrm{V}}$ virus (black bars) by NK cells derived from individuals that expressed KIR2DL2 $(n=6)$. NK cells derived from individuals that did not express KIR2DL2 (white bars, $n=6$ ) did not significantly inhibit either virus. *, $P<0.05$; **, $P<0.005$; +, KIR2DL2-positive; -, KIR2DL2-negative. All results are given as mean and s.e.m. 
or the $\mathrm{Vpu}-\mathrm{Env}^{\mathrm{V} / \mathrm{V}}$ virus (Fig. 2a-c). Consistent with the viral inhibition data, CD158b ${ }^{+} \mathrm{NK}$ cells from KIR2DL2 ${ }^{+}$individuals were strongly activated by $\mathrm{CD}^{+} \mathrm{T}$ cells infected with the $\mathrm{Vpu}-$ Env ${ }^{\text {WT/WT }}$ virus, but not by $\mathrm{CD}^{+}{ }^{+} \mathrm{T}$ cells infected with the VpuEnv $^{\mathrm{V} / \mathrm{V}}$ virus (Fig. $2 \mathrm{a}-\mathrm{c}$ ). These data are consistent with a model in which the inhibitory NK-cell receptor KIR2DL2 does not bind to cells infected with HIV-1 strains containing the Vpu-Env ${ }^{\mathrm{WT} / \mathrm{WT}}$ sequence, but can bind to cells infected with HIV-1 Vpu-Env ${ }^{\mathrm{V} / \mathrm{V}}$, providing a strong inhibitory signal to KIR2DL2 ${ }^{+} \mathrm{NK}$ cells and thereby protecting cells infected with $\mathrm{Vpu}-\mathrm{Env}^{\mathrm{V} / \mathrm{V}}$ viruses from lysis by NK cells.

KIR2DL2 segregates with KIR2DL3, as an allele of the same locus ${ }^{13}$, and is in strong linkage disequilibrium with KIR2DS2 (Wn, weighted normalized statistic for linkage disequilibrium $=0.976, P<0.001$ ), therefore most individuals in our cohort expressed both these KIRs. However, the three individuals in our cohort who expressed KIR2DL2 in the absence of KIR2DS2 also encoded the $\mathrm{Vpu}(71 \mathrm{M})$ polymorphism, indicating that KIR2DL2, not KIR2DS2, is responsible for the association with this polymorphism. To test whether KIR2DL2 was directly involved in the recognition of the viral variants, a KIR2DL2-IgG fusion construct was used to assess whether the $\mathrm{Vpu}-\mathrm{Env}^{\mathrm{V} / \mathrm{V}}$ polymorphism modulated the interaction of KIR2DL2 with HIV-1-infected CD4 ${ }^{+}$ T cells. The KIR2DL2 fusion construct bound robustly to all uninfected $\mathrm{CD} 4^{+} \mathrm{T}$ cells, and also bound to $\mathrm{CD} 4^{+} \mathrm{T}$ cells infected with the HIV-1 Vpu-Env ${ }^{\mathrm{V} / \mathrm{V}}$ variant significantly better than to $\mathrm{CD} 4^{+} \mathrm{T}$ cells from the same donor infected with the Vpu-Env ${ }^{\mathrm{WT} / \mathrm{WT}}$ variant (Fig. 2d-f). In contrast, the binding of a KIR2DL3 fusion construct to HIV-1-infected $\mathrm{CD}^{+}{ }^{+} \mathrm{T}$ cells was not significantly affected by the KIR2DL2-associated polymorphism (Fig. 2e, f). HLA-C group 1 and group 2 molecules serve as the ligands for the inhibitory receptor KIR2DL2, which has been shown to bind with greater affinity to HLA-C group 1 than group 2 (ref. 13). Staining with the KIR2DL2 fusion construct was consistent with these results, because it bound most strongly to cells from individuals homozygous for HLA-C group 1 (Supplementary Fig. 3). Consistent with these binding data, the $\mathrm{Vpu}-\mathrm{Env}^{\mathrm{V} / \mathrm{V}}$ polymorphisms were significantly enriched in KIR2DL2 ${ }^{+}$individuals homozygous for HLAC group $1(P=0.008$ for $\mathrm{Vpu}(71 \mathrm{M})$ and $P=0.01$ for $\mathrm{Vpu}(74 \mathrm{H}))$. Taken together, these data indicate that the $\mathrm{Vpu}-\mathrm{Env}^{\mathrm{V} / \mathrm{V}}$ polymorphism enhances the ability of the inhibitory receptor KIR2DL2 to bind to HIV-1-infected cells, in particular those expressing the ligands with highest affinity for KIR2DL2.

In addition to the $\mathrm{Vpu}(71 \mathrm{M} / 74 \mathrm{H})$ polymorphism, two additional amino-acid polymorphisms (Gag(138L/I) and Nef(9S/K)) were associated with the presence of the KIR2DL2 gene in the study population (Table 1, polymorphisms 2 and 22). We next determined whether these KIR2DL2-associated polymorphisms were also associated with differential recognition of HIV-1-infected cells by KIR2DL2 ${ }^{+} \mathrm{NK}$ cells. Viruses containing the polymorphisms replicated similarly in $\mathrm{CD}^{+}{ }^{+} \mathrm{T}$ cells (Supplementary Fig. 2b). As observed for the Vpu and Env variants, viruses containing the amino acids that were rarely observed in KIR2DL2 ${ }^{+}$individuals (Gag ${ }^{\mathrm{WT}}$ and $\mathrm{Nef}^{\mathrm{WT}}$, Table 2 and Supplementary Tables 4 and 5) were inhibited more strongly by NK cells derived from KIR2DL2 ${ }^{+}$individuals than were viruses containing the variants selected in KIR2DL2 ${ }^{+}$subjects (Fig. 3a, c). Furthermore, $\mathrm{KIR} 2 \mathrm{DL} 2{ }^{+} \mathrm{NK}$ cells degranulated more robustly in response to $\mathrm{CD} 4{ }^{+}$ $\mathrm{T}$ cells infected with the Gag ${ }^{\mathrm{WT}}$ and $\mathrm{Nef}^{\mathrm{WT}}$ viruses (Fig. 3b, d), and KIR2DL2-IgG fusion constructs bound significantly less to CD4 ${ }^{+}$ $\mathrm{T}$ cells infected with the Gag ${ }^{\mathrm{WT}}$ and $\mathrm{Nef}^{\mathrm{WT}}$ viruses than to cells infected with $\mathrm{Gag}^{\mathrm{V}}$ and $\mathrm{Nef}^{\mathrm{V}}$ viruses (Fig. $4 \mathrm{a}-\mathrm{c}$ ). Taken together, these data demonstrate that HIV-1 may evolve in KIR2DL2 ${ }^{+}$individuals to enrich particular amino-acid polymorphisms, in an effort to escape recognition by KIR2DL2 ${ }^{+}$NK cells.

Increasing amounts of evidence indicate that NK cells have an important role in the control of HIV-1 infection ${ }^{4-6}$. Here we report several amino-acid polymorphisms within the HIV-1 clade B sequence that are significantly associated with the expression of specific KIR genes on the population level. We demonstrate in functional studies that these 'KIR footprints' can modulate the interaction of $\mathrm{KIR}^{+} \mathrm{NK}$ cells with HIV-1-infected $\mathrm{CD} 4^{+} \mathrm{T}$ cells. The selection of particular
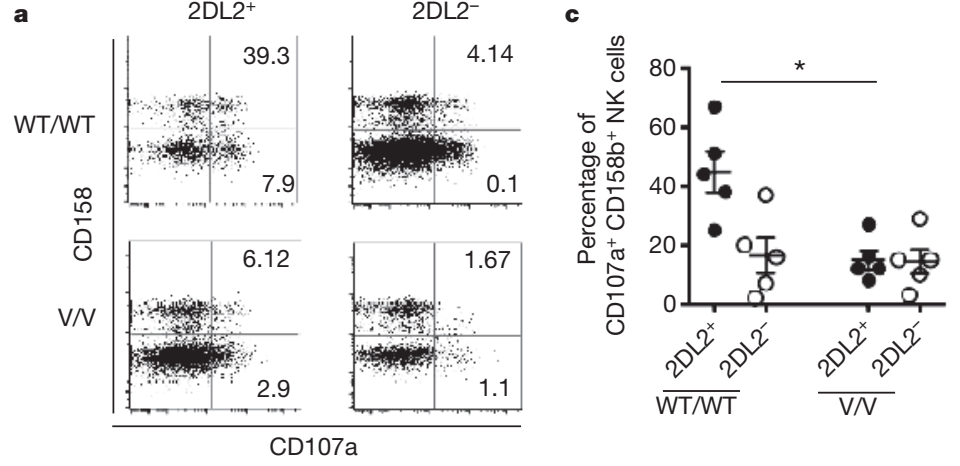

b
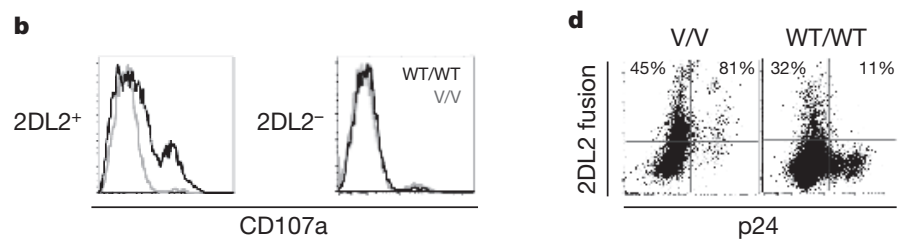
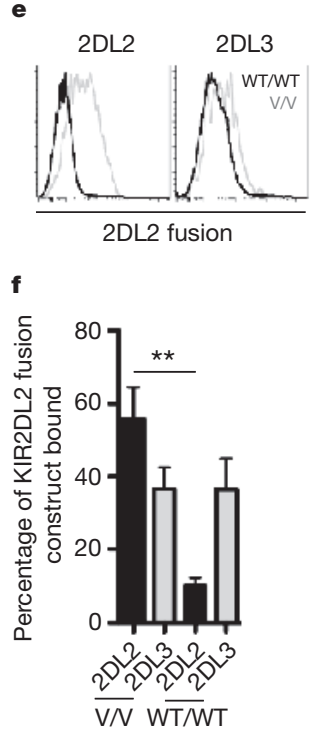

Figure $2 \mid$ Amino-acid polymorphisms at positions 71 and 74 in Vpu inhibit KIR2DL2, but not KIR2DL3, recognition and binding. a, Flow cytometric plots depicting the percentages of total CD158b(KIR2DL2/2DL3/2DS2) ${ }^{+} \mathrm{NK}$ cells that degranulated after co-culture with autologous $\mathrm{CD}^{+}{ }^{+} \mathrm{T}$ cells infected with the $\mathrm{Vpu}-\mathrm{Env}{ }^{\mathrm{WT} / \mathrm{WT}}$ virus or the $\mathrm{Vpu}-\mathrm{Env}^{\mathrm{V} / \mathrm{V}}$ virus for two representative subjects (left panels, KIR2DL2 ${ }^{+}$subjects; right panels, KIR2DL2- ${ }^{-}$subjects). b, The percentage of degranulating $\mathrm{CD} 158^{+} \mathrm{NK}$ cells in the total CD $158^{+} \mathrm{NK}-$ cell population is also represented in histograms for both the KIR2DL2 ${ }^{+}$donor (left panel) and KIR2DL2 ${ }^{-}$donor (right panel), for both the WT/WT virus (black line) and the V/V virus (grey line). c, Combined data for NK-cell degranulation in KIR2DL2 ${ }^{+}(n=5)$ and KIR2DL2 ${ }^{-}(n=5)$ individuals. $*, P<0.05$. d, Staining pattern of a KIR2DL2-IgG fusion construct on HIVinfected $\mathrm{CD} 4^{+} \mathrm{T}$ cells from an HLA-C1/C2 heterozygous donor. Percentages indicate the percentage of $\mathrm{p} 24^{-}$or $\mathrm{p} 24^{+}$cells that were stained with the KIR2DL2-IgG fusion construct. e, Staining of KIR2DL2-IgG and KIR2DL3IgG fusion constructs on the same donors infected with the WT/WT and V/V viral variants. f, Summary of binding data for the KIR2DL2-IgG (black) and KIR2DL3-IgG (grey) fusion constructs for five different HLA-C1 heterozygous $\mathrm{CD} 4{ }^{+}$T-cell donors after infection with the two viral variants. **, $P<0.005$. All results are given as mean and s.e.m. 
a

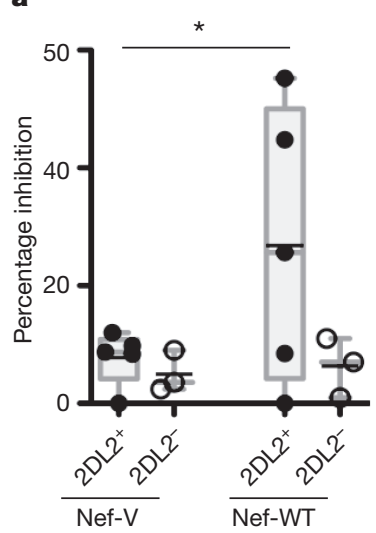

C

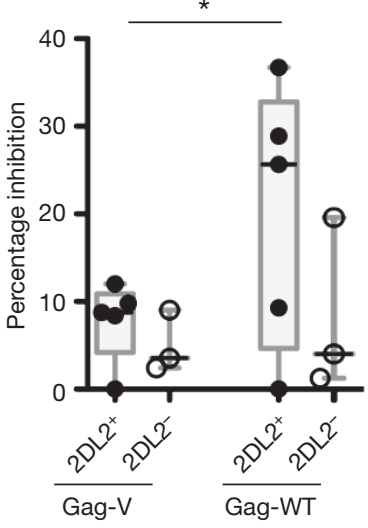

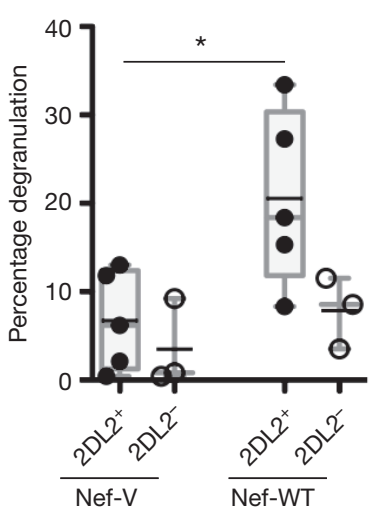

d

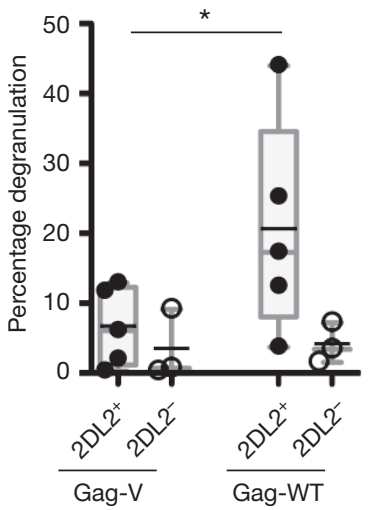

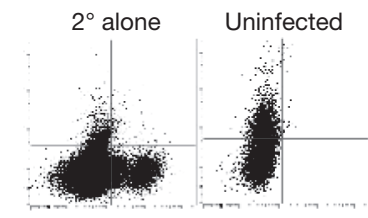
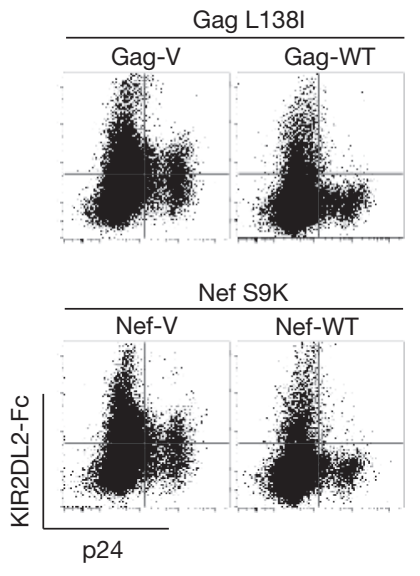

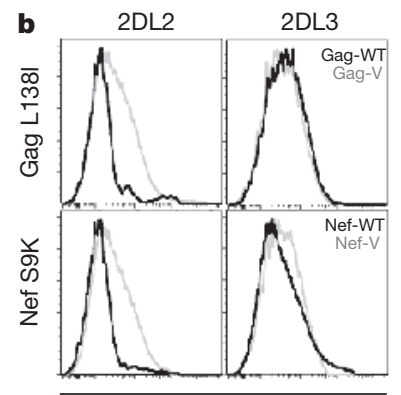

Fusion construct

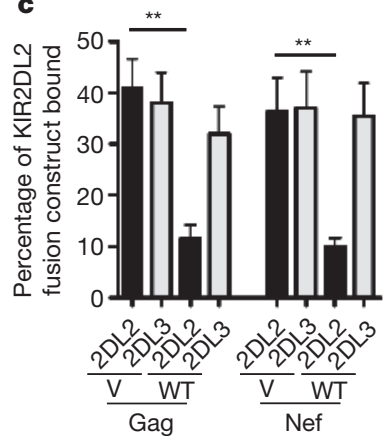

Figure $4 \mid$ KIR2DL2-associated amino-acid polymorphisms affect binding of KIR2DL2, but not KIR2DL3, to infected $\mathrm{CD}^{+}{ }^{+} \mathrm{T}$ cells. $\mathrm{CD}^{+} \mathrm{T}$ cells infected with variant viruses were stained with KIR2DL2-IgG and KIR2DL3-IgG fusion constructs. a, b, The dot plots (a) and histograms (b) show the staining pattern of KIR2DL2-IgG and KIR2DL3-IgG fusion constructs on HIV-1infected $\mathrm{CD} 4{ }^{+} \mathrm{T}$ cells from a HLA-C1/C2 heterozygous donor. $\mathrm{c}$, The bar graph summarizes binding data for KIR2DL2 (black) or KIR2DL3 (grey) IgG fusion constructs for five different HLA-C1/C2 heterozygous $\mathrm{CD} 4^{+}$T-cell donors infected with viral variants. ${ }^{* *}, P<0.005$. All results are given as mean and s.e.m.

Figure 3 Two additional KIR2DL2-associated amino-acid polymorphisms reduce KIR2DL2-mediated NK-cell recognition of virally infected cells. a, c, NK cells from KIR2DL2 ${ }^{+}$individuals $(n=5)$ inhibited the replication of the Nef-WT virus and the Gag-WT virus significantly better than they inhibited replication of the Nef- $\mathrm{V}$ and Gag-V viruses. b, d, NK cells derived from KIR2DL2 ${ }^{+}$individuals $(n=5)$ were activated significantly more by cells infected with the Nef-WT and Gag-WT viruses than by cells infected with Nef$\mathrm{V}$ and Gag-V viruses. However, NK cells derived from KIR2DL2 ${ }^{-}$individuals $(n=3)$ did not inhibit viral replication or degranulate in response to cells infected with either of the wild-type or variant viruses. ${ }^{*}, P<0.05$. All results are given as mean and s.e.m.

amino-acid residues that result in enhanced binding of inhibitory KIRs to infected cells represents a novel approach by which HIV-1 can evade NK-cell-mediated immunity. The molecular mechanisms and precise receptor-ligand interactions involved in this evasion of NK-cell recognition require further investigation. Previous in vitro studies have demonstrated that sequence variations in HLA-class-I-presented epitopes $^{14-23}$ and small changes in the peptide repertoire presented on HLA class I molecules ${ }^{24}$ can both modulate the binding of KIR, providing a potential mechanism for virus-sequence-dependent recognition of infected cells by NK cells. The KIR2DL2-associated sequence polymorphisms studied here had no impact on KIR2DL2 binding to transporter associated with antigen processing (TAP)deficient T2 cells expressing HLA-Cw*0102 (Supplementary Fig. 4), despite some degree of HLA-Cw*0102 stabilization. However, several different HLA-C group 1 molecules might present epitopes in these regions of HIV-1, resulting in differential recognition by KIR2DL2. Additionally, other mechanisms besides the modulation of KIR binding to HLA class I might account for the observed reduction in recognition of variant-virus-infected cells by KIR2DL2 ${ }^{+}$NK cells. KIR-associated sequence polymorphisms in HIV-1 proteins might directly modulate the ability of these proteins to be processed and presented ${ }^{25}$, might subtly alter hydrostatic interactions with KIR, or might change the

profile of NK-cell receptor ligands expressed on infected cells, as has been described for HIV-1 Nef, Vpu and Vpr ${ }^{26,27}$.

Protective effects of specific KIRs or combinations of KIR and HLA class I have been described for many infectious diseases, including HIV, hepatitis C virus and human papilloma virus. Although KIR2DL2 has not been identified as a protective KIR gene in any of these viral infections, homozygosity of its allotypic counterpart, KIR2DL3, has been associated with the resolution of hepatitis $\mathrm{C}$ infection when KIR2DL3 is co-expressed with its ligand, HLA-C group 1 (ref. 28). This protective KIR2DL3/HLA-C group 1 combination provides a weaker inhibitory signal, resulting in weaker inhibition of NK celll $^{28}$. Here we describe a mechanism by which HIV-1 selects for sequence polymorphisms in KIR2DL2 ${ }^{+}$individuals that lead to an enhanced binding of this inhibitory KIR to infected cells, resulting in the inhibition of NK-cell function and thereby enabling HIV-1 to escape the potential protective role of this KIR. Overall, the data from different viral infections are consistent with a model in which enhanced NK-cell activity can contribute to the control of viral replication, and indicate that viruses can evade this NK-cell-mediated immune pressure by selecting for variants that modulate the recognition of infected cells by KIR.

\section{METHODS SUMMARY}

Viral sequencing. Genomic DNA was extracted from samples of peripheral blood mononuclear cells and nested PCR protocols were used to amplify HIV-1 genomes ${ }^{9}$. Phylogenetic analysis of KIR-associated sequence polymorphisms. A decisiontree approach ${ }^{10}$, followed by adjustment for multiple comparisons, was used to identify KIR-associated sequence polymorphisms.

Construction of viruses containing sequence polymorphisms. Mutations of interest were inserted into the HIV-1 NL4-3 backbone using the GeneTailor site-directed mutagenesis system ${ }^{11,12}$.

Viral inhibition assay. Viral inhibition assays were performed after infecting $\mathrm{CD}^{+} \mathrm{T}$ cells with viral constructs, as indicated. The level of viral inhibition was 
then calculated as the difference between viral production (p24 Gag) in wells containing autologous $\mathrm{NK}$ cells and production in wells containing $\mathrm{CD} 4^{+} \mathrm{T}$ cells alone ${ }^{6}$. NK-cell degranulation assay. Degranulation of KIR2DL2 ${ }^{+} \mathrm{NK}$ cells was examined by flow cytometry after co-culture of NK cells with autologous $\mathrm{CD} 4^{+} \mathrm{T}$ cells infected with the viral construct indicated, in the presence of Golgi-stop and anti-CD107aPECy 5 for $6 \mathrm{~h}$ (ref. 29). NK cells were stained with anti-CD3, anti-CD56, anti-CD16 and anti-CD158b (KIR2DL2/2DL3/2DS2) antibodies, and the level of degranulation was assessed as the proportion of $\mathrm{CD} 107 \mathrm{a}^{+} \mathrm{NK}$ cells among the $\mathrm{CD} 158 \mathrm{~b}^{+} \mathrm{NK}$ cells.

Full Methods and any associated references are available in the online version of the paper at www.nature.com/nature.

\section{Received 14 December 2009; accepted 31 May 2011.}

1. Lanier, L. L. Up on the tightrope: natural killer cell activation and inhibition. Nature Immunol. 9, 495-502 (2008).

2. Yokoyama, W. M. Specific and non-specific natural killer cell responses to viral infection. Adv. Exp. Med. Biol. 560, 57-61 (2005).

3. Lanier, L. L. NK cell recognition. Annu Rev Immunol 23, 225-274 (2004).

4. Martin, M. P. et al. Epistatic interaction between KIR3DS1 and HLA-B delays the progression to AIDS. Nature Genet. 31, 429-434 (2002).

5. Martin, M. P. etal. Innate partnership of HLA-B and KIR3DL1 subtypes against HIV1. Nature Genet. 39, 733-740 (2007).

6. Alter, G. et al. Differential natural killer cell mediated inhibition of HIV-1 replication based on distinct KIR/HLA subtypes. J. Exp. Med. 204, 3027-3036 (2007)

7. Altfeld, M. \& Goulder, P. 'Unleashed' natural killers hinder HIV. Nature Genet. 39 , 708-710 (2007).

8. Goulder, P. J. \& Watkins, D. I. HIV and SIV CTL escape: implications for vaccine design. Nature Rev. Immunol. 4, 630-640 (2004).

9. Wang, Y. E. et al. Protective HLA class I alleles that restrict acute-phase $\mathrm{CD} 8^{+} \mathrm{T}$-cell responses are associated with viral escape mutations located in highly conserved regions of human immunodeficiency virus type 1. J. Virol. 83, 1845-1855 (2009).

10. Carlson, J. M. et al. Phylogenetic dependency networks: inferring patterns of CTL escape and codon covariation in HIV-1 Gag. PLOS Comput. Biol. 4, e1000225 (2008).

11. Schneidewind, A. et al. Escape from the dominant HLA-B27-restricted cytotoxic T-lymphocyte response in Gag is associated with a dramatic reduction in human immunodeficiency virus type 1 replication. J. Virol. 81, 12382-12393 (2007).

12. Adachi, A. et al. Production of acquired immunodeficiency syndrome-associated retrovirus in human and nonhuman cells transfected with an infectious molecular clone. J. Virol. 59, 284-291 (1986).

13. Moesta, A. K. et al. Synergistic polymorphism at two positions distal to the ligand binding site makes KIR2DL2 a stronger receptor for HLA-C than KIR2DL3. J. Immunol. 180, 3969-3979 (2008).

14. Stewart, C. A. et al. Recognition of peptide-MHC class I complexes by activating killer immunoglobulin-like receptors. Proc. Natl Acad. Sci. USA 102, 13224-13229 (2005).

15. Stewart-Jones, G. B. et al. Crystal structures and KIR3DL1 recognition of three immunodominant viral peptides complexed to HLA-B*2705. Eur. J. Immunol. 35 , 341-351 (2005).

16. Boyington, J. C., Motyka, S. A., Schuck, P., Brooks, A. G. \& Sun, P. D. Crystal structure of an NK cell immunoglobulin-like receptor in complex with its class I MHC ligand. Nature 405, 537-543 (2000).

17. Thananchai, H. et al. Cutting edge: allele-specific and peptide-dependent interactions between KIR3DL1 and HLA-A and HLA-B. J. Immunol. 178, 33-37 (2007).
18. Rajagopalan, S. \& Long, E. O. The direct binding of a p58 killer cell inhibitory receptor to human histocompatibility leukocyte antigen (HLA)-Cw4 exhibits peptide selectivity. J. Exp. Med. 185, 1523-1528 (1997).

19. Malnati, M. S. et al. Peptide specificity in the recognition of MHC class I by natural killer cell clones. Science 267, 1016-1018 (1995).

20. Peruzzi, M., Parker, K. C., Long, E. O. \& Malnati, M. S. Peptide sequence requirements for the recognition of $\mathrm{HLA}-\mathrm{B} * 2705$ by specific natural killer cells. J. Immunol. 157, 3350-3356 (1996)

21. Mandelboim, O., Wilson, S. B., Vales-Gomez, M., Reyburn, H. T. \& Strominger, J. L. Self and viral peptides can initiate lysis by autologous natural killer cells. Proc. Natl Acad. Sci. USA 94, 4604-4609 (1997).

22. Mandelboim, O. et al. The binding site of NK receptors on HLA-C molecules. Immunity 6, 341-350 (1997).

23. Fadda, L. et al. Common HIV-1 peptide variants mediate differential binding of KIR3DL1 to HLA-Bw4 molecules. J. Virol. 85, 5970-5974 (2011).

24. Fadda, L. et al. Peptide antagonism as a mechanism for NK cell activation. Proc. Natl Acad. Sci. USA 107, 10160-10165 (2010).

25. Le Gall, S., Stamegna, P. \& Walker, B. D. Portable flanking sequences modulate CTL epitope processing. J. Clin. Invest. 117, 3563-3575 (2007).

26. Ward, J. et al. HIV-1 Vpr triggers natural killer cell-mediated lysis of infected cells through activation of the ATR-mediated DNA damage response. PLoS Pathog. 5, e1000613 (2009).

27. Ward, J. et al. HIV modulates the expression of ligands important in triggering natural killer cell cytotoxic responses on infected primary T-cell blasts. Blood 110, 1207-1214 (2007).

28. Khakoo, S. I. etal. HLA and NK cell inhibitory receptor genes in resolving hepatitis $\mathrm{C}$ virus infection. Science 305, 872-874 (2004).

29. Alter, G., Malenfant, J. M. \& Altfeld, M. CD107a as a functional marker for the identification of natural killer cell activity. J. Immunol. Methods 294, 15-22 (2004).

Supplementary Information is linked to the online version of the paper at www. nature.com/nature.

Acknowledgements These studies were supported by National Institutes of Health (NIH)/National Institute of Allergy and Infectious Diseases grants R01 Al067031 (M.A.) and P01 Al074415 (M.A. and T.M.A.), and by the Doris Duke Charitable Foundation (M.A.). This project was funded in whole or in part with federal funds from the National Cancer Institute (NIH) under contract HHSN261200800001E. The content of this publication does not necessarily reflect the views or policies of the Department of Health and Human Services, nor does mention of trade names, commercial products or organizations imply endorsement by the US government. This research was supported in part by the Intramural Research Program of the NIH, National Cancer Institute, Center for Cancer Research. S.I.K. is a recipient of a Wellcome Trust Senior Clinical Fellowship and M.A. is a Distinguished Clinical Scientist of the Doris Duke Charitable Foundation. We thank Microsoft Research, the Bill \& Melinda Gates Foundation, the Mark and Lisa Schwartz Foundation and the Phillip T. and Susan M. Ragon Foundation for their support

Author Contributions G.A. conducted the immunology experiments and L.F. performed the KIR-staining experiments on T2 cell lines. A.S. and C.O.-N. constructed the viral variants. D.H., C.M.K. and J.M.C. performed the data analysis identifying KIR-associated polymorphisms. B.L. and T.M.A. performed the viral sequencing, M.C. and M.M. performed the HLA and KIR typing, and L.F. and S.I.K. provided the KIR fusion construct. G.A. and M.A. planned the studies, prepared the manuscript and supervised the project.

Author Information Reprints and permissions information is available at www.nature.com/reprints. The authors declare no competing financial interests. Readers are welcome to comment on the online version of this article at www.nature.com/nature. Correspondence and requests for materials should be addressed to M.A. (maltfeld@partners.org). 


\section{METHODS}

Study subjects. Ninety-one untreated subjects chronically infected with HIV-1 subtype B, for which HLA class I and KIR genotypes were available (Supplementary Table 1), were included in this study ${ }^{9}$. In addition, 100 HIV-1 negative controls were genotyped for KIR and HLA genotypes. Of this large cohort of uninfected controls, 15 subjects that were KIR2DL2 ${ }^{+}\left(\mathrm{KIR}^{+} \mathrm{DL} 2^{+} / \mathrm{KIR} \mathrm{DLL} 3^{+}\right)$ and 15 subjects that were KIR2DL2 ${ }^{-}\left(\mathrm{KIR}_{2} \mathrm{DL} 3^{+} / \mathrm{KIR}^{+} \mathrm{DL} 3^{+}\right)$were enrolled to provide samples for the generation of NK cells and autologous $\mathrm{CD} 4^{+}$target cells (Supplementary Table 6). For these in vitro studies, only individuals that did not encode KIR3DS1 and HLA-B Bw4-80I were selected, because we had previously observed very strong inhibition of HIV-1 replication in vitro in individuals with this combined KIR/HLA genotype ${ }^{6}$. All study subjects were enrolled in Boston through the Massachusetts General Hospital, the Lemuel-Shattuck Hospital and the Fenway Community Health Center. The study was approved by the Massachusetts General Hospital Review Board and all subjects gave written informed consent.

Viral sequencing. Genomic DNA was extracted from peripheral blood mononuclear cell samples and nested PCR protocols were used to amplify HIV-1 genomes as described previously ${ }^{9}$. Five independent PCR products of each sample were pooled and directly population-sequenced at the Massachusetts General Hospital DNA sequencing core facility using clade B consensus sequencing primers, as previously described 9 .

HLA class I and KIR typing. High-resolution HLA class I typing and KIR genotyping were performed as described previously.

Phylogenetic analysis of KIR-associated sequence polymorphisms. We used the decision-tree approach ${ }^{10}$, which corrects for phylogenetic structure among the sequences and allows for a multivariate analysis, to identify KIR-associated sequence polymorphisms. All results were adjusted for multiple comparisons (both $P$ and $Q$ values are assigned to each result). For each protein analysed, a maximum likelihood phylogenetic tree was constructed from the corresponding sequences. For every KIR and HLA gene, amino-acid position and amino acid at that position, we created two generative or directed graphical models of the observed presence or absence of the amino acid in each sequence: one representing the null hypothesis that the observations are generated by the phylogenetic tree alone and the other representing the alternative hypothesis that additional escape or reversion takes place owing to KIR/HLA pressure in the subjects for which the sequences are observed. The likelihood of the observations was then maximized over the parameters of both models using an expectation-maximization algorithm, and a $P$ value was computed using a likelihood ratio test based on those likelihoods ${ }^{10}$. To increase power, the tests were binarized, such that the presence or absence of a given KIR or HLA gene was correlated with the presence or absence of a given amino acid. In addition, KIR-polymorphism pairs were analysed only when the actual or expected count in every cell of the corresponding two-by-two contingency table was $\geq 3$. For every amino acid at each position, the KIR or HLA gene with the strongest association (and its corresponding $P$ value) was added to the list of identified associations. The analysis was then repeated after removing individuals having or possibly having this KIR or HLA gene. This procedure was iterated until no KIR or HLA gene yielded an association with a $P$ value less than 0.05 . A $Q$-value statistic, estimating the proportion of false positives among the associations identified, was computed for each association by repeating this analysis on null data (generated by permuting the KIR/HLA data). Correction for multiple comparisons was undertaken using both $Q<0.05$ (estimating 5\% false positives) and $Q<0.2$ (estimating $20 \%$ false positives).

Construction of viruses containing sequence polymorphisms. The HIV-1 strain NL4-3 was modified to express one or two mutations in vpu/env, nef or gag using the GeneTailor site-directed mutagenesis system (Invitrogen) or the QuikChange Lightning site-directed mutagenesis system (Stratagene) ${ }^{11,12}$. In brief, mutagenesis was performed using $5^{\prime}$ oligonucleotide primers Vpu_M71R-f (CTTGTGGAGATGGGGGTGGAAAGGGGGCACCAT (nucleotide (nt) 6279)), Vpu_M71R-r (TTTCCACCCCCATCTCCACAAGTGCTGATACTTCT (nt 6234)), Vpu_H74L-f (ATGGGGGTGGAAATGGGGCACCTTGCTCCTTGG), Vpu_H74L-r (GGTGCCCCATTTCCACCCCCATCTCCACAAG $($ (nt 6247)), Vpu_M71R/H74L-f (ATGGGGGTGGAAAGGGGGCACCTTGCTCCTTGG (nt 6247 and nt 6288)) and Vpu_M71R/H74L-r (GGTGCC̈CCCTTTCCACCCCCATCTCCACAAG (nt 6247)); Nef/S9K-f (GTGGTCAAAAAGTĀAAGTGATTGGATGGCC (nt 8827)) and Nef/S9K-r (GGCCATCCAATCACTTTACTTTTTGACCAC (nt 8798)); Gag/L138I-f (CCTATAGTGCAGAACATCCAGGGGCAAATGG (nt 1216)) and Gag/L138I-r (CCATTTGCCCCTGGĀTGTTCTGCACTATAGG (nt 1186)). Mutated nucleotides are underlined and primer positions are numbered according to the numbering of NL4-3 (GenBank accession number AF324493). The complete HIV-1 coding region of the variant proviruses was sequenced on an ABI3730 XL DNA analyser. Propagation of provirus and generation of viral stocks was performed as previously described ${ }^{11,12}$. Although the full-length sequence of the NL4-3 viruses differed from the autologous sequence of the respective study subjects, the areas flanking the $v p u, g a g$ and nef sequences studied were identical between the NL4-3 virus and the respective areas of interest, and only differed in the amino acids indicated in Supplementary Tables 2-5.

Viral inhibition assay. Viral inhibition assays using NK cells were performed as previously described ${ }^{6}$. $\mathrm{CD} 4^{+}$T cells that were generated after 4 days in culture with a bi-specific antibody to $\mathrm{CD} 3$ and $\mathrm{CD} 8$ were infected with laboratory strains containing amino-acid polymorphisms at a multiplicity of infection of 0.01 for $4 \mathrm{~h}$ at $37^{\circ} \mathrm{C}$. Cells were washed twice. Equal numbers of $\mathrm{CD} 4^{+} \mathrm{T}$ cells were plated at NK-cell/CD4 ${ }^{+} \mathrm{T}$ cell ratios of 10:1, or alone, for 14 days in the presence of $50 \mathrm{U} \mathrm{ml}^{-1}$ interleukin-2. Supernatant was collected every 3-4 days for quantification of p24 Gag production by enzyme-linked immunosorbent assay (p24 ELISA; Perkin Elmer).

NK-cell degranulation assay. To examine whether KIR2DL2 ${ }^{+}$NK cells specifically degranulated in response to autologous $\mathrm{CD} 4^{+} \mathrm{T}$ cells infected with either of the viral variants, we monitored the level of CD107a upregulation on KIR2DL2 ${ }^{+}$or KIR2DL2 ${ }^{-}$NK cells ${ }^{29}$. We selected HIV-1-negative donors that expressed KIR2DL2 in the absence of KIR2DS2 (referred to as KIR2DL2 ${ }^{+}$), or KIR2DL3 in the absence of KIR2DL2 and KIR2DS2 (referred to as KIR2DL2 ${ }^{-}$). An antiCD158b antibody was used to detect NK cells expressing KIR2DL2, KIR2DL3 and KIR2DS2. The level of degranulation was assessed as the proportion of CD107a ${ }^{+}$ NK cells among the $\mathrm{CD} 158 \mathrm{~b}^{+} \mathrm{NK}$ cells. NK cells thus purified were co-cultured in the presence of autologous $\mathrm{CD} 4^{+} \mathrm{T}$ cells infected in vitro with the respective HIV-1 strains for 7 days. Monensin was added to co-cultures on day 7 at $0.3 \mu \mathrm{g} \mathrm{ml}^{-1}$, in the presence of $20 \mu \mathrm{l} \mathrm{CD107a-PE-Cy5}$, for $6 \mathrm{~h}$. Cells were washed and stained with CD3-Pacific Blue, CD56-PE-Cy7, CD16-APC-Cy7 (BD Biosciences) and CD158b-PE (Beckman Coulter) for $30 \mathrm{~min}$, then washed and fixed in 1\% paraformaldehyde until flow cytometric analysis was performed (FACSCalibur; BD Biosciences).

KIR-IgG fusion construct binding assay. Differences in the ability of KIR2DL2 or KIR2DL3 to interact with $\mathrm{CD} 4^{+} \mathrm{T}$ cells infected with either of the viral variants were ascertained using KIR2DL2-IgG and KIR2DL3-IgG fusion constructs (provided by S. Khakoo and O. Mandelboim). Peripheral blood mononuclear cells were obtained from HLA-C1/C1 homozygotes, HLA-C1/C2 heterozygotes or HLA-C2/C2 homozygotes, and were treated with $0.3 \mu \mathrm{g}$ of a bispecific CD3/ $\mathrm{CD} 8$ antibody in the presence of $50 \mathrm{U}$ interleukin-2 per ml of complete medium. After 3 days, the cells were infected with one of the three KIR2DL2-associated variants (Vpu-71/74, Gag-138 or Nef-9), or with wild-type virus, for 2 days. The cells were then collected and stained with $2 \mu \mathrm{l}$ of the KIR2DL2-IgG or KIR2DL3IgG for $1 \mathrm{~h}$ on ice. The cells were then washed and stained with a secondary allophycocyanin (APC)-conjugated goat anti-human IgG antibody for an additional $20 \mathrm{~min}$ on ice. In parallel, infected cells were stained with the anti-human antibody alone to define the background level of staining. All cells were then fixed with $100 \mu \mathrm{l}$ of Fix A solution (Invitrogen) for $10 \mathrm{~min}$, washed and permeabilized using $100 \mu \mathrm{l}$ of Perm B (Invitrogen). The cells were then stained for intracellular p24 using the KC-57-RD1 antibody for $20 \mathrm{~min}$ on ice, and then washed. Cells were fixed in $1 \%$ paraformaldehyde until flow cytometric analysis was performed (FACSCalibur; BD Biosciences).

HLA class I stabilization assays. HLA-C stabilization was assessed in $2 \times 10^{5} \mathrm{~T} 2$ cells that were incubated with $0.04 \mathrm{mg} \mathrm{ml}^{-1}$ peptide, as indicated, overnight at $26^{\circ} \mathrm{C}$. The following day, peptide-pulsed T2 cells were stained with W632-PE (eBioscience) antibody (HLA-A/B/C) or DT9 antibody (HLA-C/E) for $30 \mathrm{~min}$ at $4{ }^{\circ} \mathrm{C}$. Cells were then washed in PBS before staining with anti-mouse IgG-PE (Sigma) for 30 min at $4{ }^{\circ} \mathrm{C}$. Cells were washed twice with PBS and fixed in Perm A solution (BD Biosciences). KIR2DL2-IgG binding to peptide-pulsed T2 cells was assessed as previously described ${ }^{24}$. 


\section{Supplemental Figure 1}

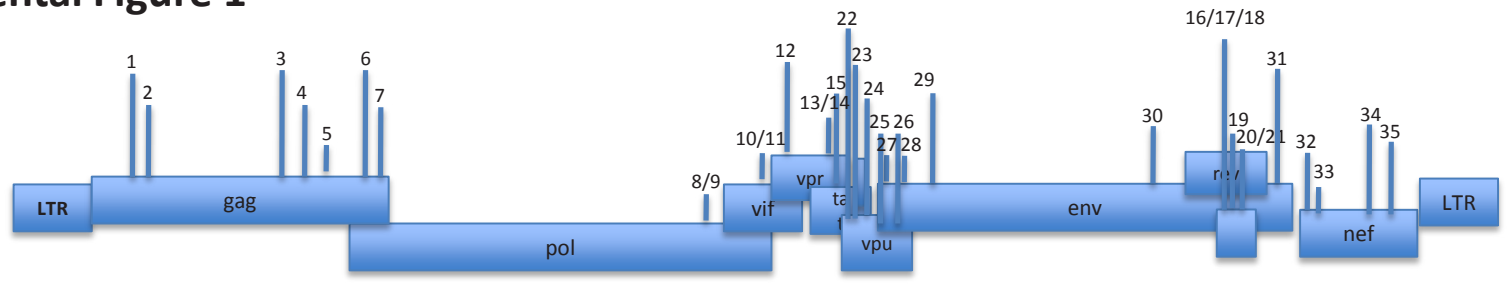

Supplemental Figure 1: Distribution of KIR associated polymorphisms across the viral genome. The figure depicts the distribution of KIR -associated polymorphisms across the HIV genome. The bulk of the mutations cluster within variable genes that are expressed early during the viral life-cycle. Numbers correspond to numbers in Table 1. 


\section{Supplemental Figure 2}

a

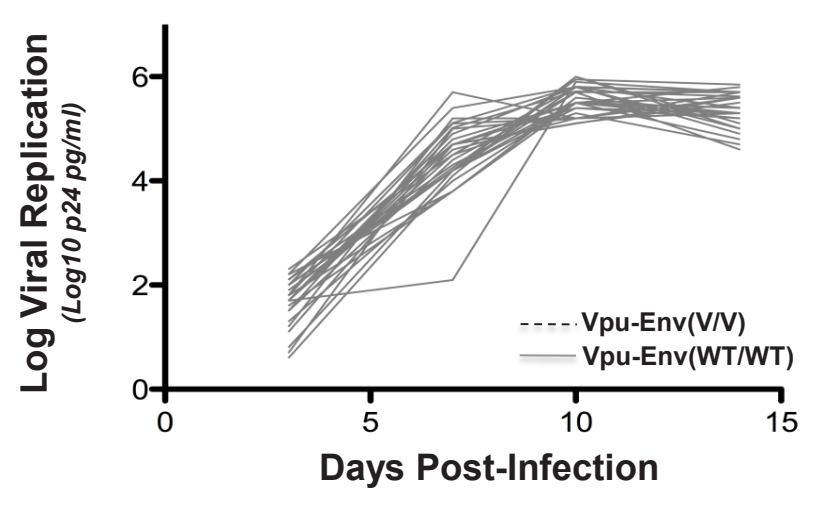

b

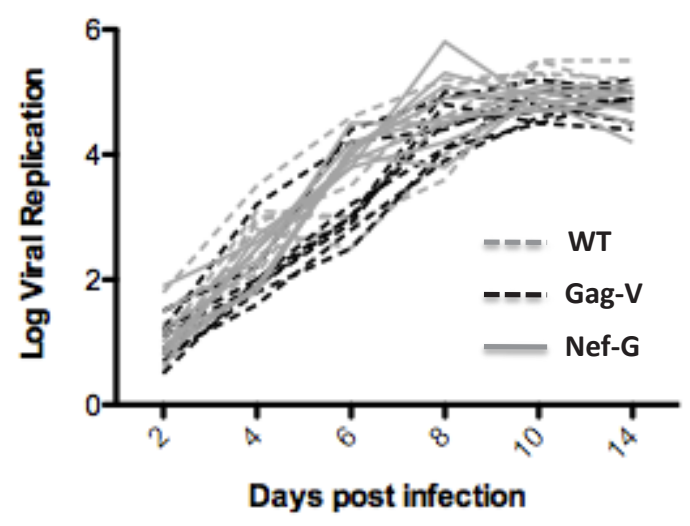

Supplemental Figure 2: Replication of the different viral constructs in CD4+ T cells in the absence of NK cells. No differences in the replication capacity were observed among the wildtype (WT) and variant (V) viruses. 


\section{Supplemental Figure 3}

A

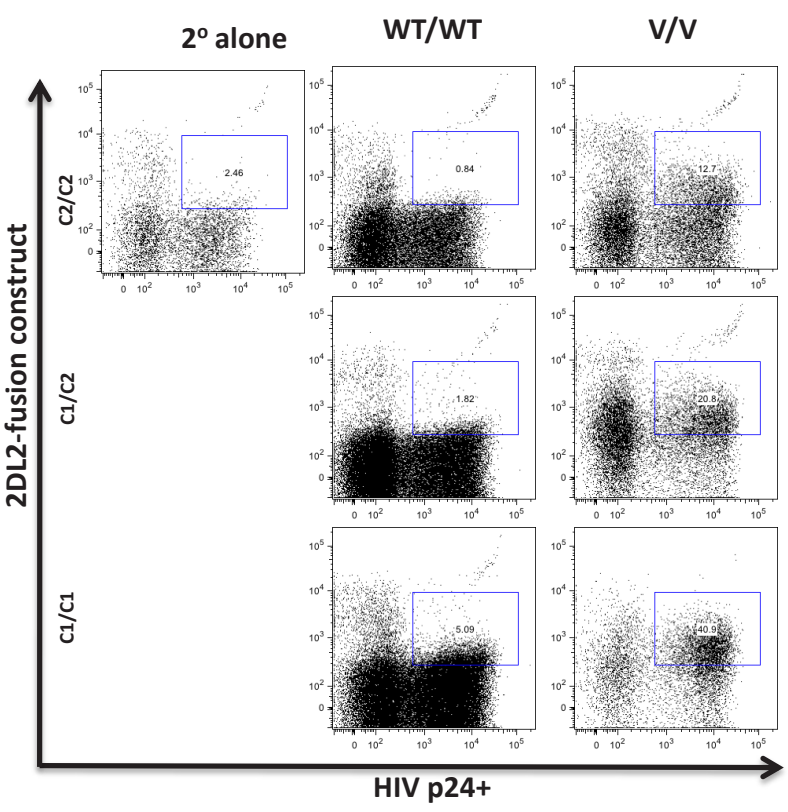

B

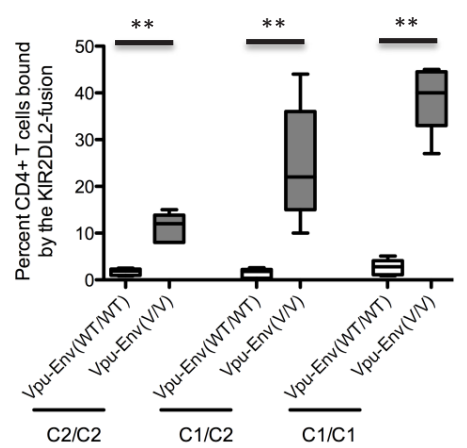

Supplemental Figure 3: Amino acid polymorphisms at positions 71/74 in VPU inhibit KIR2DL2 binding in an HLAC1 dependent manner. To determine whether a particular subgroup of HLA-C (KIR2DL2 ligands) was associated with differential KIR2DL2 mediated recognition of the viral polymorphisms, differences in the capacity of KIR2DL2 to interact with CD4+ T cells infected with the mutant or wild-type virus was compared using a KIR2DL2-IgG fusion construct. HIV-1-infected CD4+ T cells isolated from donors encoding for HLA-C group $1 / 1,2 / 2$, or $1 / 2$ were stained. Significantly stronger binding to $\mathrm{C} 1 / \mathrm{C} 1+$ than to $\mathrm{C} 2 / \mathrm{C} 2+\mathrm{CD} 4+\mathrm{T}$ cells infected with the variant virus was observed. ${ }^{* *} p<0.005$. 


\section{Supplemental Figure 4}

$\boldsymbol{a}$

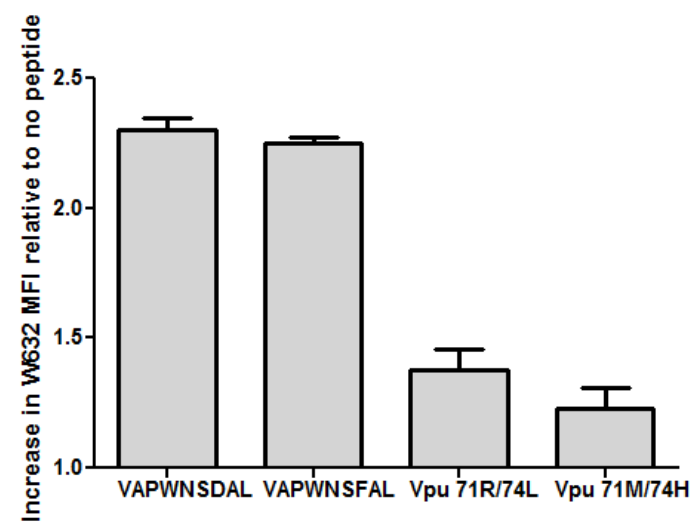

C

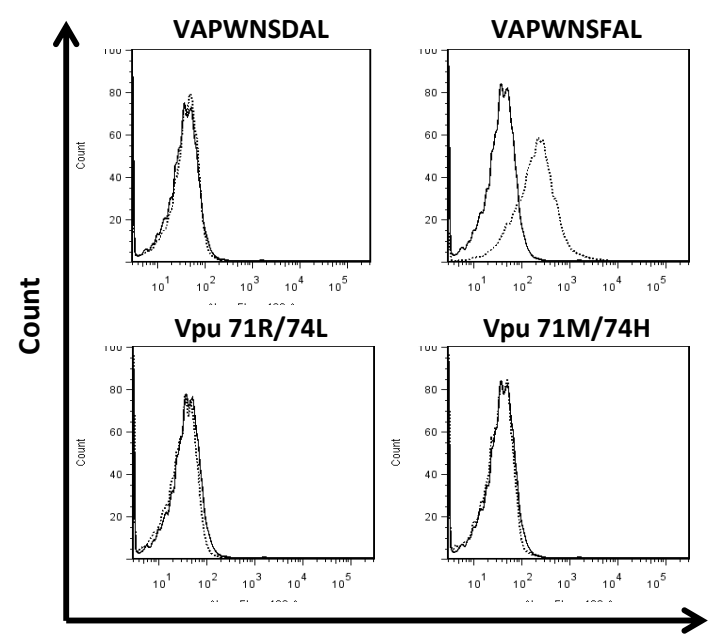

KIR-Fc- Alexa 488

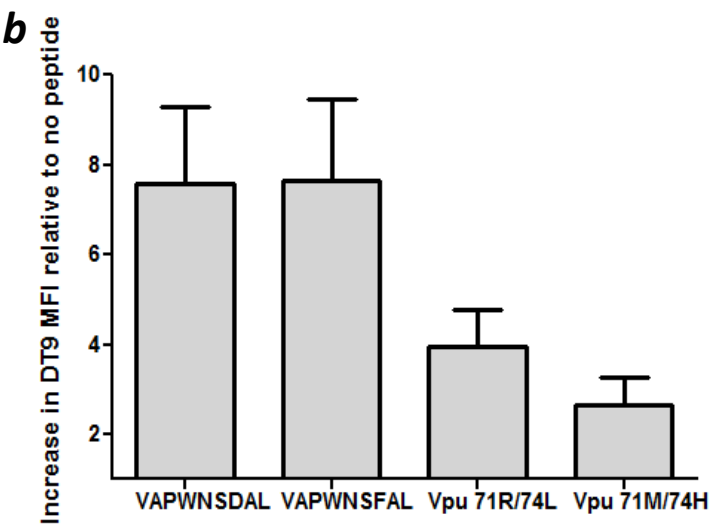

Supplemental Figure 4: Stabilization of HLA-Cw*0102expression on $\mathrm{T} 2$ cells by $\mathrm{Vpu}$ peptides and KIR2DL2 binding. T2 cells (HLA-A1, -B51 and $-\mathrm{Cw}^{*} 0102$ ) were incubated overnight at $26 \mathrm{C}$ with $0.04 \mathrm{mg} / \mathrm{ml}$ of the $\mathrm{HLA}^{-C w^{*} 0102-r e s t r i c t e d}$ epitope peptides VAPWNSDAL or VAPWNSFAL ${ }^{24}$, or with the peptides spanning the wild-type and variant sequences in $\mathrm{Vpu}$ (Vpu MH: SALVEMGVEMGHHAPWD; Vpu RL: SALVEMGVE $\underline{R} G H L A P W D)$. HLA class I stabilization was assessed by staining with a) W632 (binding to HLA-A,-B,-C) ( $n=5)$ or b) DT9 (binding to HLA-C,-E) $(n=5)$. Fold increase in MFI relative to $\mathrm{MFI}$ of $\mathrm{T} 2$ cells in the absence of peptide is shown. $\mathrm{C}$ ) Flow cytometry histogram plots of the binding of isotype control (KIR3DS1-Fc) or KIR2DL2-Fc (dotted line) in the presence of the indicated peptides. In addition, overlapping 9-mer and 10-mer peptides spanning the entire $\mathrm{Vpu}$ region were tested, however none of those peptides resulted in KIR2DL2-binding (data not shown). 


\begin{tabular}{|c|c|c|c|c|c|c|c|c|}
\hline 2 & '0201 & '2402 & '0720 & '4402 & '0501 & '0702 & '1 & '1 \\
\hline 3 & '3002 & '3303 & '4403 & '4403 & '0304 & '0401 & '1 & '1 \\
\hline 4 & '0201 & '2601 & '3801 & '4402 & '0501 & 1203' & '1 & '1 \\
\hline 5 & '0101 & '2902 & '1510 & '3910 & '0401 & 1203' & '1 & '1 \\
\hline 6 & '0101 & '0301 & '1402 & '5701 & '0602 & '0802 & '1 & 1 \\
\hline 7 & '0301 & '2601 & '0702 & '4402 & '0501 & '0702 & '0 & '1 \\
\hline 8 & 0201 & 2402 & 1801 & 5501 & 0303 & 0701 & '1 & '1 \\
\hline 9 & '0101 & '1101 & '3501 & '2705 & 0202 & '0401 & '1 & '1 \\
\hline 10 & 0101 & 0201 & 0801 & 4402 & 0501 & 0701 & '1 & '1 \\
\hline 11 & 1101' & '2402 & '1402 & '5501 & '0304 & '0802 & '1 & '1 \\
\hline 12 & '2301 & $' 7400$ & '0801 & '1402 & '0701 & '0802 & '1 & '1 \\
\hline 13 & 0201 & 1101 & 1501 & 4402 & 0303 & 0501 & '1 & '1 \\
\hline 14 & '2402 & '3201 & '0705 & '1302 & '0602 & '1505 & '1 & '1 \\
\hline 15 & '2601 & '2902 & '4403 & '4901 & '0701 & '1601 & '1 & '1 \\
\hline 16 & '2902 & '6801 & '4002 & '5201 & '0202 & '1505 & '1 & '1 \\
\hline 17 & 2601 & 7401 & 3701 & 4901 & 0602 & 0701 & '1 & '1 \\
\hline 18 & '0201 & '3101 & '5101 & '5101 & '0102 & '0401 & '1 & '1 \\
\hline 19 & 2402 & 3012 & 3503 & 5703 & 0701 & 1203 & '1 & '1 \\
\hline 20 & '7401 & '8001 & '1801 & '5703 & '0202 & '0701 & '1 & '1 \\
\hline 21 & '0101 & '6801 & '0801 & '5702 & '0701 & '1800 & '1 & '1 \\
\hline 22 & 0201 & 3201 & 4402 & 5101 & 0501 & 1502 & '1 & '1 \\
\hline 23 & '0201 & '3002 & '1503 & '5101 & '0210 & '1602 & '1 & '1 \\
\hline 24 & '0101 & '2601 & '2705 & '5601 & '0102 & & '1 & '1 \\
\hline 25 & '3303 & '7401 & '1503 & '5801 & '0202 & '0701 & '1 & '1 \\
\hline 26 & 2902 & 6802 & 4403 & 5802 & 1601 & 0602 & '1 & '1 \\
\hline 27 & '1101 & '6801 & 1501 & '1803 & '0303 & '0701 & '1 & '1 \\
\hline 28 & 2402 & 8001 & 2705 & 5301 & 0202 & 0401 & '1 & '1 \\
\hline 29 & '0201 & '3303 & '0705 & '4403 & '0303 & '1505' & '1 & '1 \\
\hline 30 & 0205 & 2902 & 1402 & 5801 & 0701 & 0802 & '1 & '1 \\
\hline 31 & 0201 & 0301 & 1501 & 3501 & 0303 & 0401 & '1 & '1 \\
\hline 32 & '0101 & '0101 & '0801 & '5701 & '0602 & '0701 & '1 & '1 \\
\hline 33 & '0202 & '6801 & '1401 & '1401 & '0210 & '0804 & '1 & '1 \\
\hline 34 & '0301 & '3002 & '0702 & '1801 & '0501 & '0702 & '1 & '1 \\
\hline 35 & 0201 & 6801 & 0702 & 4402 & 0702 & 0704 & '1 & '1 \\
\hline 36 & 0101 & 1101 & 3501 & 5501 & 1402 & 0303 & '1 & '1 \\
\hline 37 & '2301 & '6801 & '1402 & '5802 & '0602 & '0802 & '1 & '1 \\
\hline 38 & '2301 & '3402 & '4403 & '8101 & '0401 & '1801 & '1 & '1 \\
\hline 39 & 6801 & 6802 & 0702 & 0801 & 0702 & 0701 & '1 & '1 \\
\hline 40 & '1101 & '6801 & '4402 & '5802 & '0501 & '0602 & '1 & '1 \\
\hline 41 & 0101 & 0201 & 2705 & 3701 & 0602 & 1203 & '1 & '1 \\
\hline 42 & '0201 & '3101 & '0702 & '1531 & '0407 & '0702 & '1 & '1 \\
\hline 43 & 0201 & 3402 & 3501 & 4501 & 0401 & 1601 & '1 & '1 \\
\hline 44 & '2301 & '2601 & '0702 & '5301 & '0602 & '0702 & '1 & '1 \\
\hline 45 & '0201 & '3002 & '1801 & '0801 & '0501 & '20 & '1 & '1 \\
\hline 46 & '0202 & '3012 & '5301 & '5801 & '0802 & '0401 & '1 & '1 \\
\hline 47 & 0201 & 3601 & 5301 & 2705 & 0102 & 0401 & '1 & '1 \\
\hline 48 & '0202 & '3002 & '4901 & '7801 & '0701 & '1601 & '1 & '0 \\
\hline 49 & '0301 & '2501 & 1501' & '4001 & '0304 & '0304 & '1 & 0 \\
\hline 50 & '0101 & '0301 & '0702 & '0702 & '0702 & '0702 & '1 & '0 \\
\hline 51 & '2402 & '6801 & '0702 & '1302 & '0702 & '0802 & '1 & '0 \\
\hline 52 & '0301 & '3002 & '1801 & '0801 & '0501 & '0702 & '1 & '0 \\
\hline 53 & 0202 & 2902 & 0702 & 4901 & 0701 & 0701 & '1 & '0 \\
\hline 54 & '0101 & '3201 & '0801 & '1801 & '0701 & '0701 & '1 & 0 \\
\hline 55 & '0101 & '0301 & '0702 & '3508 & '0401 & '0702 & '1 & '0 \\
\hline 56 & 1101 & 3201 & 0702 & 3503 & 0702 & 1202 & '1 & '0 \\
\hline 57 & '0201 & '2601 & '0801 & '4402 & '0501 & '0702 & '1 & '0 \\
\hline 58 & 0201 & 0301 & 4001 & 5101 & 0102 & 0304 & '1 & '0 \\
\hline 59 & '0301 & '1101 & '0702 & '3901 & '0702 & '1203 & '1 & '0 \\
\hline 60 & '0301 & '6802 & '1510 & '3501 & 0304 & '0401 & '1 & '0 \\
\hline 61 & '2902 & '3101 & '3512 & '4002 & '0202 & '0401 & '1 & '0 \\
\hline 62 & '2301 & '2902 & '4403 & '4403 & '1601 & '1601 & '1 & '0 \\
\hline 63 & '0101 & '0201 & '1801 & '2705 & '0202 & '1203 & '1 & 0 \\
\hline 64 & '0101 & '0201 & '0702 & '3512 & '0401 & '0702 & '1 & '0 \\
\hline 65 & '0101 & '1101 & '0801 & '3504 & '0401 & '0701 & '1 & '0 \\
\hline 66 & '2402 & '3201 & '1502 & '5101 & '0801 & '1602 & '1 & '0 \\
\hline 67 & '0101 & '2402 & '0801 & '1801 & '0701 & '1203 & '1 & '0 \\
\hline 68 & '0201 & '2301 & '4501 & '4501 & '0602 & '0602 & '1 & '0 \\
\hline 69 & 0101 & 0101 & 1402 & 4403 & 0501 & 1601 & '1 & '0 \\
\hline 70 & '1101' & '2501 & '3501 & '3901 & '0401 & '1203 & '1 & '0 \\
\hline 71 & '0101 & '3001 & '0702 & '4201 & 1505' & '1700 & '1 & '0 \\
\hline 72 & '0201 & '0301 & '1801 & '4403 & '0701 & '1602 & '1 & 0 \\
\hline 73 & '0101 & '0201 & '0801 & '5101 & '0701 & '1502 & '1 & '0 \\
\hline 74 & 33 & 68 & 1510 & 5301 & 0304 & 0401 & '1 & 0 \\
\hline 75 & '0301 & '2301 & '0702 & '4501 & '0602 & '0702 & '1 & 0 \\
\hline 76 & '2902 & '6801 & '4002 & '5201 & '0202 & '1502 & '1 & 0 \\
\hline 77 & 0217 & 2601 & 0801 & 4002 & 0305 & 0701 & '1 & '0 \\
\hline 78 & '0217 & '2601 & '0801 & '4002 & '0305 & '0701 & '1 & '0 \\
\hline 79 & '0201 & '0204 & '4402 & '5101 & '0501 & '1502 & '1 & '0 \\
\hline 80 & '3601 & '6802 & '1510 & '1516 & '0304 & '1402 & '1 & '0 \\
\hline 81 & 0201 & 6801 & 1501 & 5501 & 0303 & 0501 & '1 & 0 \\
\hline 82 & '0301 & '2423 & '3501 & '5101 & '0401 & '1402 & '1 & 0 \\
\hline 83 & '0204 & '0205 & '5101 & 5301 & '0401 & '1502 & '1 & 0 \\
\hline 84 & '0201 & '0202 & '3501 & '4501 & 1402' & '1601 & '1 & 0 \\
\hline 85 & '0101 & '0201 & '5101 & '5703 & '1601 & '0701 & '1 & 0 \\
\hline 86 & '0301 & '3601 & '4402 & '0401 & '0501 & & '1 & 0 \\
\hline 87 & '0301 & '6802 & '4403 & '5301 & '0401 & '0401 & '1 & 0 \\
\hline 88 & '0201 & '0301 & '3502 & '4402 & '0401 & '0704 & '1 & 0 \\
\hline 89 & '0201 & '0301 & '3901 & '0702 & '0701 & '0702 & '1 & '0 \\
\hline 90 & '0201 & '1101 & '3503 & '4001 & '0304 & '0401 & '1 & 0 \\
\hline 91 & 0101 & 6802 & 1510 & 5802 & 0304 & 0602 & 1 & \\
\hline
\end{tabular}




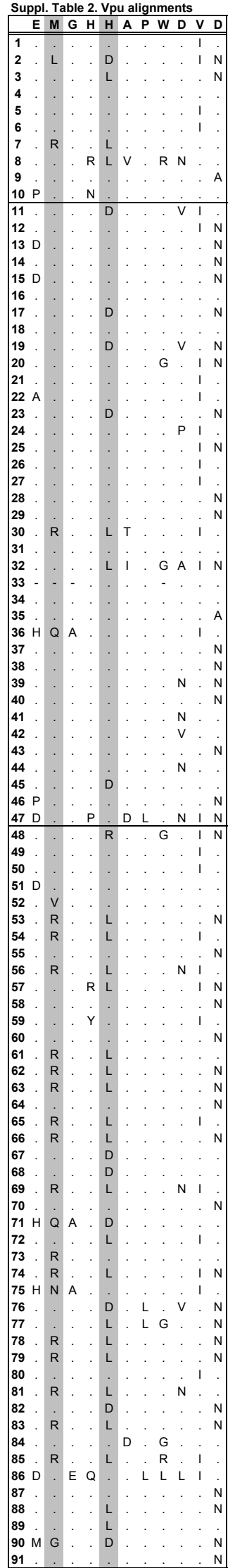



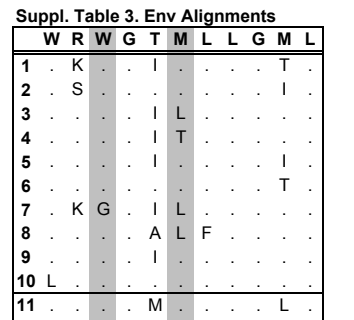

12 .

13 G i

$14 . \mathrm{K}$

16
17

$\begin{array}{lll}17 & . \\ 18\end{array}$

19 .

21 . K

$22 \cdot$.

23 . K . M

25 .

26 . K

$28 \cdot \vec{k}$

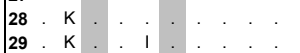

30. K G I L . i

31.

33

$34 \cdot \mathrm{K}$

35 i

36

37 .

38 .

39.

41 .

42 .

$\begin{array}{lll}43 & \text {. } & \mathrm{K} \\ 44 & \text {. } \\ 45 & \text {. } \\ 46 & & \end{array}$

$\begin{array}{lll}45 & \mathrm{~L} & \mathrm{Q} \\ 46 & & \end{array}$

$46 \mathrm{~L}$

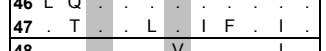

49 .

50 . K

$\begin{array}{lll}51 & R & T\end{array}$

52 . .

53 . K G . L

54.

55 .

56 .

\begin{tabular}{ll}
57 & $\cdot$ \\
58 & $\cdot$ \\
59 & $\mathrm{~K}$ \\
\hline & $\mathrm{K}$
\end{tabular}

$59 \cdot \mathrm{K}$

60.
61.
62.

63.

$\begin{array}{lllll}64 & & & \\ 65 & \mathrm{~K} & \mathrm{G} & \mathrm{I} & \mathrm{L}\end{array}$

$\begin{array}{ll}66 & \\ 67 & \mathrm{~K}\end{array}$

68 .

$68 \cdot \cdot$. M .

70 .

72 .

72 ... I L . . I

73 G G i i . :

75 G T $M$ L

76 . . . M . F. L

77 . K . . L

78 . G . . L

79. K G. I L . . .

81.. .

82 . K

83. K G I L

84 . . . . . . I

85. K G . I L . . . I

86. $T$. S S F C L

87.

88 .

. I L

$90 \mathrm{~K} \mathrm{~W}$ G . M

91 


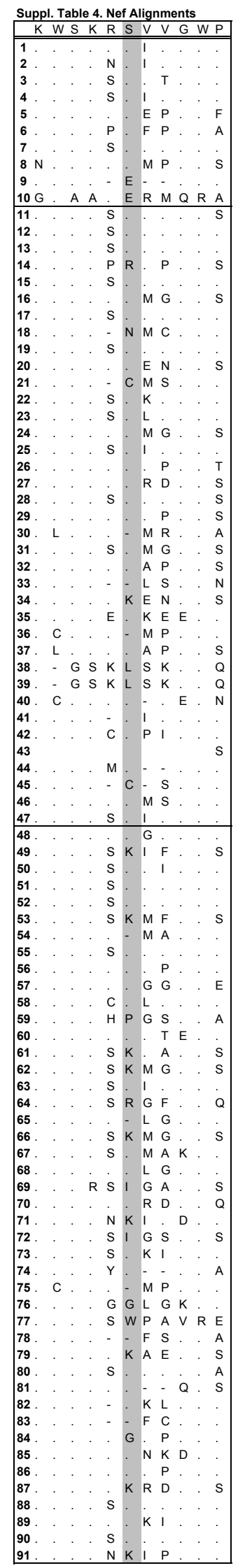


SUPPLEMENTARY INFORMATION RESEARCH

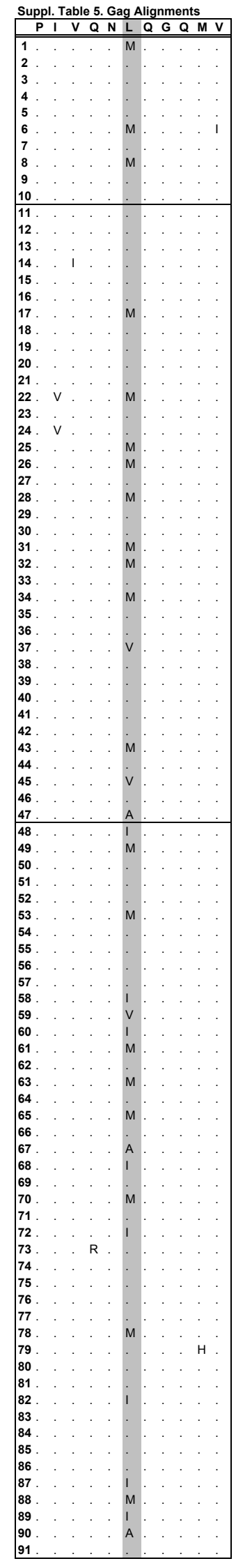


RESEARCH SUPPLEMENTARY INFORMATION

Supplemental Table 6. KIR and HLA class I genotypes of Healthy Donors 2DL1 2DL2 2DL3 2DL4 2DL5 2DS1 2DS2 2DS3 2DS5 3DL1 3DS1 3DL2 3DL3 HLA-A1 HLA-A2 HLA-B1 HLA-B2 HLA-C1 HLA-C2C grou

\begin{tabular}{|c|c|c|c|c|c|c|c|c|c|c|c|c|c|c|c|c|c|c|c|c|}
\hline 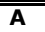 & $\bar{~} 1$ & 1 & $\overline{1.1}$ & $\bar{~} 1$ & 0 & 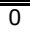 & $\overline{1} 1$ & 0 & $\overline{00}$ & 1 & $\overline{c 0}$ & $\bar{~} 1$ & $\bar{~} 1$ & 0301 & "6802 & 0702 & 141402 & 0702 & 0802 & C1 C1 \\
\hline B & 1 & 1 & 1 & 1 & 0 & 0 & 1 & 0 & 0 & 1 & 0 & 1 & 1 & 0201 & 0201 & 1801 & 3901 & 0501 & 1203 & $\mathrm{C} 2 \mathrm{C} 1$ \\
\hline C & 1 & 1 & 1 & 1 & 1 & 0 & 1 & 1 & 0 & 1 & 0 & 1 & 1 & 0201 & 2402 & 3502 & 3931 & 0401 & 1203 & $\mathrm{C} 2 \mathrm{C} 1$ \\
\hline D & 1 & 1 & 1 & 1 & 0 & 0 & 1 & 0 & 0 & 1 & 0 & 1 & 1 & 0301 & 2402 & 0702 & 3906 & 0702 & 0702 & $\mathrm{C} 1 \mathrm{C} 1$ \\
\hline E & 1 & 1 & 1 & 1 & 1 & 0 & 1 & 1 & 0 & 1 & 0 & 1 & 1 & 0301 & 3201 & 0702 & 5001 & 0602 & 0702 & $\mathrm{C} 2 \mathrm{C} 1$ \\
\hline $\mathbf{F}$ & 1 & 1 & 1 & 1 & 0 & 0 & 1 & 0 & 0 & 1 & 0 & 1 & 1 & 2902 & 6802 & 1402 & 2705 & 0202 & 0804 & $\mathrm{C} 2 \mathrm{C} 1$ \\
\hline G & 1 & 1 & 1 & 1 & 0 & 0 & 1 & 0 & 0 & 1 & 0 & 1 & 1 & 0301 & 3004 & 1801 & 5108 & 1203 & 1602 & $\mathrm{C} 1 \mathrm{C} 2$ \\
\hline H & 1 & 1 & 1 & 1 & 1 & 0 & 1 & 1 & 0 & 1 & 0 & 1 & 1 & 0205 & 6801 & 3503 & 4901 & 0401 & 0701 & $\mathrm{C} 2 \mathrm{C} 1$ \\
\hline I & 1 & 1 & 1 & 1 & 0 & 0 & 1 & 0 & 0 & 1 & 0 & 1 & 1 & 0101 & 0201 & 0702 & 4102 & 0602 & 0701 & $\mathrm{C} 2 \mathrm{C} 1$ \\
\hline J & 1 & 1 & 1 & 1 & 1 & 1 & 1 & 0 & 1 & 1 & 0 & 1 & 1 & 0201 & 0302 & 3508 & 5201 & 0401 & 1202 & $\mathrm{C} 2 \mathrm{C} 1$ \\
\hline K & 1 & 1 & 1 & 1 & 1 & 0 & 1 & 1 & 0 & 1 & 0 & 1 & 1 & 0101 & 1101 & 3501 & 3701 & 0401 & 0701 & $\mathrm{C} 2 \mathrm{C} 1$ \\
\hline $\mathbf{L}$ & 1 & 1 & 1 & 1 & 0 & 0 & 1 & 0 & 0 & 1 & 0 & 1 & 1 & 2902 & 3101 & 4402 & 4501 & 0602 & 0704 & $\mathrm{C} 2 \mathrm{C} 1$ \\
\hline M & 1 & 1 & 0 & 1 & 1 & 1 & 1 & 1 & 0 & 1 & 0 & 1 & 1 & 0201 & 0201 & 0702 & 4102 & 1203 & 1602 & $\mathrm{C} 1 \mathrm{C} 2$ \\
\hline $\mathbf{N}$ & 1 & 1 & 1 & 1 & 0 & 0 & 1 & 0 & 0 & 1 & 0 & 1 & 1 & 2601 & 3101 & 2705 & 4901 & 0102 & 0701 & $\mathrm{C} 1 \mathrm{C} 1$ \\
\hline $\mathbf{O}$ & 1 & 1 & 1 & 1 & 1 & 1 & 1 & 0 & 1 & 1 & 0 & 1 & 1 & 0101 & 2402 & 3501 & 3501 & 0401 & 0701 & $\mathrm{C} 2 \mathrm{C} 1$ \\
\hline $\mathbf{P}$ & 1 & 0 & 1 & 1 & 0 & 0 & 0 & 0 & 0 & 1 & 0 & 1 & 1 & 0101 & 0201 & 0801 & 3501 & 0401 & 0701 & $\mathrm{C} 2 \mathrm{C} 1$ \\
\hline $\mathbf{Q}$ & 1 & 0 & 1 & 1 & 0 & 0 & 0 & 0 & 0 & 1 & 0 & 1 & 1 & 0201 & 2601 & 1501 & 2705 & 0102 & 0303 & $\mathrm{C} 1 \mathrm{C} 1$ \\
\hline $\mathbf{R}$ & 1 & 0 & 1 & 1 & 0 & 0 & 0 & 0 & 0 & 1 & 0 & 1 & 1 & 2501 & 3101 & 1401 & 1801 & 0802 & 1203 & $\mathrm{C} 1 \mathrm{C} 1$ \\
\hline $\mathbf{S}$ & 1 & 0 & 1 & 1 & 0 & 0 & 0 & 0 & 0 & 1 & 0 & 1 & 1 & 0205 & 2601 & 3801 & 5001 & 0602 & 1203 & $\mathrm{C} 2 \mathrm{C} 1$ \\
\hline $\mathbf{T}$ & 1 & 0 & 1 & 1 & 0 & 0 & 0 & 0 & 0 & 1 & 0 & 1 & 1 & 0301 & 3201 & 0801 & 3508 & 0401 & 0701 & $\mathrm{C} 2 \mathrm{C} 1$ \\
\hline $\mathbf{U}$ & 1 & 0 & 1 & 1 & 0 & 0 & 0 & 0 & 0 & 1 & 0 & 1 & 1 & 0201 & 1101 & 1501 & 3501 & 0303 & 0401 & $\mathrm{C} 1 \mathrm{C} 2$ \\
\hline $\mathbf{v}$ & 1 & 0 & 1 & 1 & 0 & 0 & 0 & 0 & 0 & 1 & 0 & 1 & 1 & 0201 & 0206 & 4011 & 4402 & 0304 & 0501 & $\mathrm{C} 1 \mathrm{C} 2$ \\
\hline $\mathbf{w}$ & 1 & 0 & 1 & 1 & 0 & 0 & 0 & 0 & 0 & 1 & 0 & 1 & 1 & 1101 & 2402 & 1301 & 1525 & 0304 & 0403 & $\mathrm{C} 1 \mathrm{C} 2$ \\
\hline $\mathbf{x}$ & 1 & 0 & 1 & 1 & 0 & 0 & 0 & 0 & 0 & 1 & 0 & 1 & 1 & 0201 & 0206 & 4011 & 4402 & 0304 & 0501 & $\mathrm{C} 1 \mathrm{C} 2$ \\
\hline $\mathbf{Y}$ & 1 & 0 & 1 & 1 & 0 & 0 & 0 & 0 & 0 & 1 & 0 & 1 & 1 & 0201 & 3303 & 1501 & 5801 & 0302 & 0801 & $\mathrm{C} 1 \mathrm{C} 1$ \\
\hline $\mathbf{Z}$ & 1 & 0 & 1 & 1 & 0 & 0 & 0 & 0 & 0 & 1 & 0 & 1 & 1 & 0201 & 0201 & 0702 & 5601 & 0102 & 0702 & $\mathrm{C} 1 \mathrm{C} 1$ \\
\hline AA & 1 & 0 & 1 & 1 & 0 & 0 & 0 & 0 & 0 & 1 & 0 & 1 & 1 & 0101 & 0301 & 0702 & 1501 & 0304 & 0702 & $\mathrm{C} 1 \mathrm{C} 1$ \\
\hline AB & 1 & 0 & 1 & 1 & 0 & 0 & 0 & 0 & 0 & 1 & 0 & 1 & 1 & 0201 & 3002 & 0702 & 2705 & 0102 & 0702 & $\mathrm{C} 1 \mathrm{C} 1$ \\
\hline AC & 1 & 0 & 1 & 1 & 0 & 0 & 0 & 0 & 0 & 1 & 0 & 1 & 1 & 0101 & 2601 & 0702 & 0801 & 0701 & 0702 & $\mathrm{C} 1 \mathrm{C} 1$ \\
\hline AD & 1 & 0 & 1 & 1 & 0 & 0 & 0 & 0 & 0 & 1 & 0 & 1 & 1 & 0101 & 0201 & 1801 & 5101 & 0602 & 1402 & $\mathrm{C} 2 \mathrm{C} 1$ \\
\hline
\end{tabular}

